\begin{abstract}
UNIVERSIDADE DE SÃO PAULO
FACULDADE DE FILOSOFIA, LETRAS E CIÊNCIAS HUMANAS DEPARTAMENTO DE LETRAS MODERNAS

PROGRAMA DE PÓS-GRADUAÇÃO EM LÍNGUA ESPANHOLA E LITERATURAS ESPANHOLA E HISPANO-AMERICANA
\end{abstract}

CHAYENNE ORRU MUBARACK

\title{
A CONSTRUÇÃO DE UM ESPAÇO NACIONAL EM LOS PAÍSES INVISIBLES, DE EDUARDO LALO
}

Versão corrigida

São Paulo 2020 
CHAYENNE ORRU MUBARACK

\section{A CONSTRUÇÃO DE UM ESPAÇO NACIONAL EM LOS PAÍSES INVISIBLES, DE EDUARDO LALO}

\section{Versão corrigida}

Dissertação apresentada ao Programa de Pósgraduação em Língua Espanhola e Literaturas Espanhola e Hispano-americana do Departamento de Letras Modernas da Faculdade de Filosofia, Letras e Ciências Humanas da Universidade de São Paulo, para a obtenção do título de Mestre.

Orientadora: Profa. Dra. Idalia Morejón Arnaiz

São Paulo 
Autorizo a reprodução e divulgação total ou parcial deste trabalho, por qualquer meio convencional ou eletrônico, para fins de estudo e pesquisa, desde que citada a fonte.

Catalogação na Publicação

Serviço de Biblioteca e Documentação

Faculdade de Filosofia, Letras e Ciências Humanas da Universidade de São Paulo

M941c Mubarack, Chaỹenne Orru Invisibles, de Eduardo Lalo / Chayenne Orru Mubarack ; orientadora Idalia Morejón Arnaiz. - São Paulo, 2020 .

$81 \mathrm{f}$.

Dissertação (Mestrado) - Faculdade de Filosofia, Letras e Ciências Humanas da Universidade de São Paulo. Departamento de Letras Modernas. Área de concentração: Língua Espanhola e Literaturas Espanhola e Hispano-Americana.

1. Literatura caribenha. 2. Literatura portorriquenha. 3. Ensaio latino-americano. 4. Eduardo Lalo. I. Arnaiz, Idalia Morejón, orient. II. Título. 


\section{ENTREGA DO EXEMPLAR CORRIGIDO DA DISSERTACCÃO}

\section{Termo de Ciência e Concordância do (a) orientador (a)}

Nome do (a) aluno (a): Chayenne Orru Mubarack

Data da defesa: 12/06/2020

Nome do Prof. (a) orientador (a): Idalia Morejón Arnaiz

Nos termos da legislação vigente, declaro ESTAR CIENTE do conteúdo deste EXEMPLAR CORRIGIDO elaborado em atenção às sugestões dos membros da comissão Julgadora na sessão de defesa do trabalho, manifestando-me plenamente favorável ao seu encaminhamento e publicação no Portal Digital de Teses da USP.

São Paulo, 16/07/2020

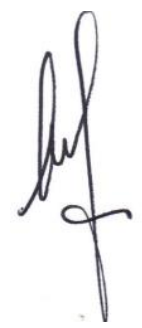

(Assinatura do (a) orientador (a) 


\section{AGRADECIMENTOS}

À minha orientadora, Idalia Morejón Arnaiz, e ao selo editorial Malha Fina Cartonera, lado a lado, por terem me apresentado ao universo da literatura caribenha, especificamente portorriquenha, e aberto a possibilidade de estuda-lo.

Aos meus pais, Lidia Orru Mubarack e Sergio Tadeu Orru Mubarack, por sempre me instigarem à leitura e acreditarem em mim quando nem eu mesma podia fazê-lo.

Aos meus amigos, Pacelli Dias Alves de Sousa e Juliana Mayumi Honda Ueno, pela fraternidade.

Aos meus companheiros latino-americanos, Rodrigo Julkim Mendoza Toro e Valentina Chendi Patrignani, por manterem a magia do continente viva em mim.

A todos os demais docentes, amigos e colegas que estiveram comigo ao longo da escrita dessa dissertação, muito obrigada. 


\section{RESUMO}

Este trabalho apresenta duas vertentes de análise sobre o livro de ensaios LoS Países Invisibles, escrito pelo portorriquenho Eduardo Lalo. A primeira, desenvolvida ao longo dos capítulos I e II, versa sobre as imagens construídas ao longo do texto para cunhar uma política de invisibilidade. O primeiro capítulo se debruça sobre as imagens aquáticas, buscando o "efeito arquipélago" que ele produz, tal como definido por Juan Carlos Quintero Herencia. Propõe-se inverter o foco da pequenez territorial da ilha para a imensidão de água que a circunda e os efeitos dela sobre o texto. $\mathrm{O}$ segundo capítulo trata das representações da cidade, delineando um panorama sobre a presença do elemento urbano na obra. Por fim, o último capítulo inaugura uma vertente mais próxima à teoria e evidencia a textualidade e o plano da enunciação para descrever a maneira em que ambos se articulam no desenvolvimento de uma "poética do pensar", conceito forjado por Liliana Weinberg. Para tal, realizamos discussões sobre o ensaio como gênero, as apropriações dele pelo campo intelectual da América Latina no final do século XIX e em meados do século XX e como ele delineia um espaço nacional no livro.

Palavras-chave: Literatura caribenha. Literatura portorriquenha. Ensaio latinoamericano. Eduardo Lalo. 


\section{ABSTRACT}

This research presents two aspects of analysis on the essay book Los Países Invisibles, written by Puerto Rican Eduardo Lalo. The first, developed over the course of chapters I and II, deals with the images constructed throughout the text to develop an invisibility policy. The first chapter focuses on aquatic images, looking for the "archipelago effect" that it produces, as defined by Juan Carlos Quintero Herencia. It is proposed to invert the focus of the island's territorial smallness to the immensity of water that surrounds it and its effects on the text. The second chapter deals with representations of the city, outlining an overview of the presence of the urban element in the work. Finally, the last chapter opens a strand closer to the theory and highlights the textuality and the enunciation plan to describe the way in which both are articulated in the development of a "poetics of thinking", a concept forged by Liliana Weinberg. In order to do it, we held discussions about the essay as a genre, its appropriations by the intellectual field of Latin America in the late 19th and mid 20th centuries and how it outlines a national space in the book.

Key words: Caribbean literature. Puerto Rican literature. Latin American essay. Eduardo Lalo. 


\section{SUMÁRIO}

INTRODUÇÃO

CAPÍTULO I - O MAR, A ÁGUA, AS ILHAS

1.1 A visibilidade enquanto condição ………………...................................... 13

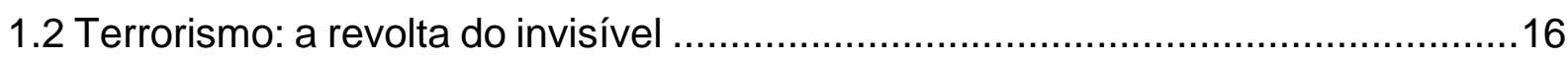

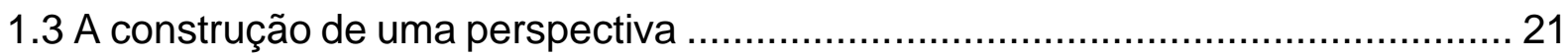

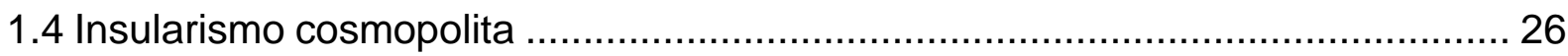

1.4.1 "Cosmopolita": de que cosmopolitismo estamos falando …............................ 28

1.5 "Um portorriquenho pode ser lido como alguém ou só como um portorriquenho?" .29

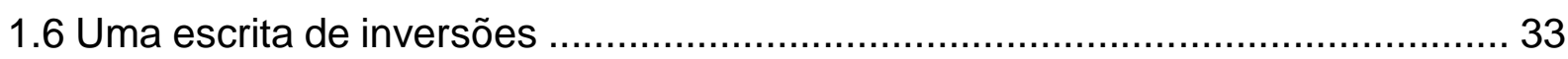

CAPÍTULO II - A TERRA, O SOLO, AS CIDADES …............................................ 40

2.1 Nômade islenho: Eduardo Lalo e o périplo ...........................................................40

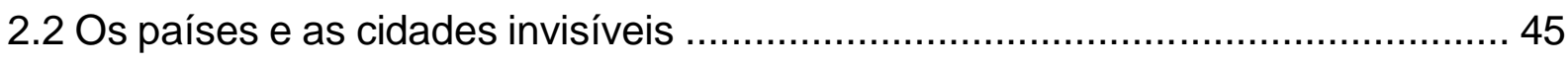

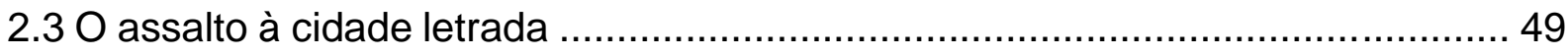

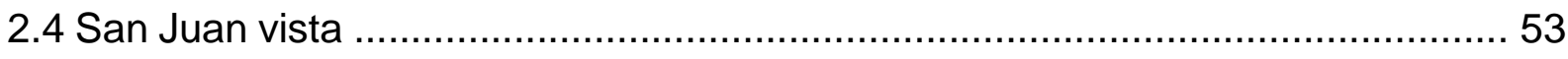

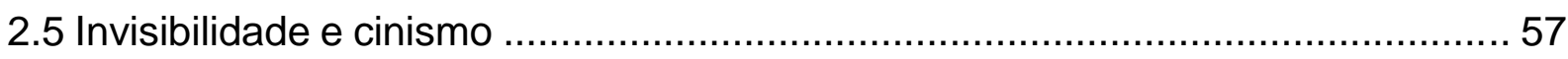

CAPÍTULO III - O ENSAIO, O ESPAÇO NACIONAL, A DIVERSIDADE ..............60

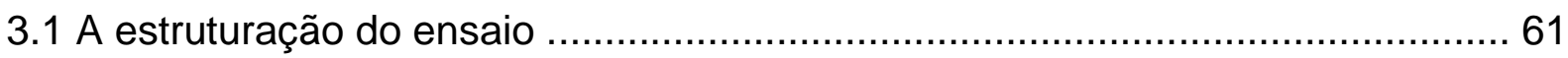

3.2 Um gênero nacional para um Estado Livre Associado ..................................... 65

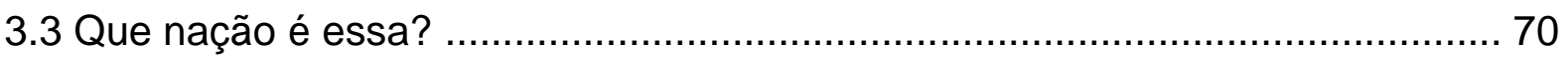

3.4 O espaço nacional em Relação.................................................................... 73

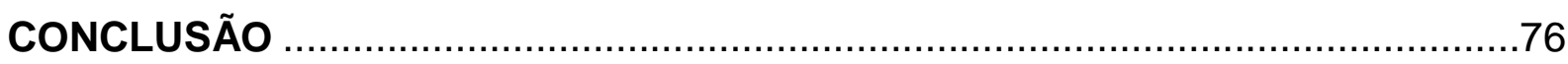

BIBLIOGRAFIA 


\section{INTRODUÇÃO}

Para não começar citando Harold Bloom forçosamente, prefiro lembrar o que disse a poeta portuguesa Matilde Campilho em uma entrevista dada à Clara Cavour, como parte do projeto "Retratos", ao falar do processo criativo de seu livro Jóquei e da "angústia das influências". A poeta diz que essa angústia trata justamente de escrever, produzir uma obra e, posteriormente, perceber que existem outras vozes ecoando em seus poemas, dar-se conta de que algo que ela leu há muito tempo atrás está presente, faz-se influência em seu processo criativo atual. Como identificar todas essas influências? Como afirmar "a partir daqui não sou eu, fala uma leitura realizada?". Essa angústia é, de fato, uma questão importante para os poetas e escritores, posto que pode acarretar em questões jurídicas, como plágio etc. Entretanto, como isso opera na mente de um leitor? Como leitores, também estamos sujeitos à angústia das influências. Sempre que lemos pensamos em semelhanças, buscamos reminiscências ou, em outras palavras, um "à luz de".

A primeira vez que eu li Los Países Invisibles, de Eduardo Lalo, o que me angustiou foi a ausência dessa angústia das influências. Me chamou a atenção o fato de não identificar na obra nenhuma semelhança com algo que eu já tivesse lido. Eu não possuía um amplo conhecimento sobre a literatura portorriquenha, nem sobre os temas que interessavam ao autor como, por exemplo, o cinismo. Justamente por isso o livro se apresentou como ainda mais interessante: meu processo automático de análise havia sido rompido por essa obra. Não foi possível realizar a leitura e pensar "esse livro me lembra aquele outro", "o autor escreve de modo parecido com esse outro autor". De certa forma, eu entrava em um ambiente novo e isso me cativou. Eu precisava preencher esse vazio, eu queria sentir essa angústia das influências com a literatura portorriquenha.

Então, eu comecei a expandir minha biblioteca de leituras caribenhas e tentei entrar cada vez mais no universo de Eduardo Lalo. Isso implicou em releituras da obra selecionada e de outros textos do autor, de outros livros e da coluna "Isla en su tinta", publicada no jornal El Nuevo Día. Também procurei conhecer e estudar grandes nomes da literatura e da ensaística portorriquenha, como Tomás Blanco, Pedro Albizu Campos, René Marqués, Antonio Pedreira, José Luis González, Luis López Nieves, Luis Rafael Sánchez, Arcadio Díaz Quiñones, Juan Carlos Quintero Herencia e Juan Duchesne Winter, para mencionar alguns. Outro universo explorado foi o da 
identidade caribenha, composto pelos mesmos autores citados anteriormente e outros como Édouard Glissant, Antonio Benítez Rojo, Jamaica Kincaid e Kamau Brathwaite.

Ao realizar essa imersão, fui tomada por um questionamento: por que meu conhecimento sobre a literatura produzida por essa ilha era tão limitado? Que tipo de barreira fora construída ao redor dela para que eu não conseguisse projetar ali meu desejo incessante de leitora de identificar influências? As influências, neste caso, sempre se dão nos dois sentidos: identificar em Lalo a influência de algo conhecido e perceber Lalo como influenciador de algo que eu já havia lido.

A resposta estava no livro que é o objeto principal dessa pesquisa. Primeiramente, pensemos no título dele: Los Países Invisibles. Um "país invisível" por seu status de Estado Livre Associado aos Estados Unidos. Uma ilha que, após a dominação espanhola, vive sob domínio político estadunidense até hoje. Talvez por essa neocolonização nos seja tão caro enxergar os discursos sobre e de autoria dos que estão nessa ilha.

A denotação da palavra "pays", em francês, não envolve apenas os EstadosNação, mas também indica uma ligação dos habitantes de um local com o território geográfico onde vivem. Esta definição está na obra, pois ela menciona, além de Porto Rico, regiões como Valença, na Espanha, que não é uma nação, mas um território, e sofre com a invisibilidade. Para além do status político, o livro de Lalo nos coloca em contato com uma questão inerente a todos os territórios que são apagados, esquecidos e invisíveis frente a um Ocidente que, nas palavras do escritor, insiste em mantê-los nessas condições. Apresenta-se a tese principal do ensaio - e também de outros textos do mesmo autor, como $A$ escrita riscada: a teoria da invisibilidade. $O$ processo de colonização significou a inclusão de certos territórios na história não a partir dos discursos que os nativos destes territórios produziam sobre si mesmos, mas sobre a reescrita desses discursos a partir da palavra dos colonizadores, a quem Lalo chama Ocidente. O Ocidente impõe seus discursos, impossibilitando que certos sujeitos os produzam.

Existem, para o autor, dois tipos de invisibilidade: a da ausência de discursos e a que se deve aos excessos. A ausência é o que mencionamos anteriormente, resultado de um Ocidente que silencia, que fala por, que risca a escrita de determinados indivíduos para inseri-los em seu universo através de uma escrita que 
o mesmo Ocidente produziu. Por outro lado, o excesso de discursos sobre um território também resulta em sua invisibilidade, pois padece do que Lalo chama de hipervisibilidade. Isso se dá, por exemplo, em Veneza, cidade turística que, por possuir demasiados discursos e imagens a seu respeito, converteu-se na cópia destes, na reprodução do que é dito sobre ela. Veneza em si invisibilizou-se nestes discursos.

As leituras realizadas e o contato com a história de Porto Rico e a teoria da invisibilidade transformaram-se nesta dissertação. Este texto divide-se em três capítulos e segue uma ordem distinta à que usualmente é adotada neste tipo de trabalho. Ao invés de iniciar com uma exposição teórica e, em seguida, mostrar as análises que dela decorrem, optei por começar com as análises e terminar com a teoria. Isso justifica-se por uma crença de que é o próprio objeto que deve encaminhar o leitor à um aparato teórico, e não a teoria que deve guiar minhas leituras.

A partir daí, apresento um primeiro capítulo que trata do papel das imagens aquáticas no livro. Qual a função da água, do mar, no ensaio de Lalo? Como o autor posiciona a ilha de Porto Rico nas águas ocidentais? O maior impulsionador dessa parte da análise foi o livro La hoja de mar (:), de Juan Carlos Quintero Herencia, que apresenta diversas leituras de textos caribenhos nos quais o foco translada da pequenez de uma ilha para sua infinidade, se considerarmos sua localização no oceano. Do verso de Virgilio Piñera, "La maldita circunstancia del agua por todas partes", para as reflexões sobre quais as possibilidades que o mar oferece a este território.

A amenização pelo atendimento à minha angústia das influências começou a operar nesse capítulo, em que busquei reminiscências de La isla que se repite, de Antonio Benítez Rojo, na construção desse território que navega pelo Ocidente. Ao pensar em uma ilha que transita, mobilizei textos como Robinson Crusoe, citado pelo próprio ensaísta e referência obrigatória para pensarmos sobre a experiência do naufrágio e uma ilha que ninguém, além dos que nela estão, vê. Também aproximei o ensaio A escrita riscada, do mesmo autor, e a primeira parte de Los países invisibles, aos diários de Cristóvão Colombo, primeiro texto em que o Ocidente risca os discursos de outros para inserir o seu próprio sobre eles. As imagens aquáticas no ensaio me permitiram vislumbrar a criação de uma perspectiva própria de Eduardo Lalo, de certa forma ambígua, pois ser de um "país invisível", a partir do qual não se espera nenhum 
discurso, é o que impulsiona e possibilita a escritura do autor, conforme explorarei ao longo do capítulo.

Se o primeiro capítulo está centralizado na água, o segundo se direciona à terra, mais especialmente ao território de Porto Rico explorado por Lalo: a cidade de San Juan de Puerto Rico. Este capítulo trabalha com as imagens e representações que o autor delineia sobre sua cidade. O primeiro capítulo tem como foco a escrita, ao passo que o segundo se debruça sobre a leitura. Aqui, as influências se fazem cada vez mais presentes. Inicialmente analiso, a partir de semelhanças entre os títulos, e posteriormente em diversos âmbitos, Los Países Invisibles à luz de Las ciudades invisibles, de Italo Calvino. Sigo com aproximações em relação à $A$ cidade das letras, de Angel Rama, e o livro que considero seu sucessor, La ciudad vista, de Beatriz Sarlo. Com base nessas aproximações, as representações de San Juan se tornam mais visíveis e dialogam diretamente com a "teoria da invisibilidade" desenvolvida pelo autor.

Estes dois capítulos iniciais abordam, portanto, os dois eixos temáticos que considero principais no livro escolhido. De certo modo, posso dizer que sanaram minha angústia por influências, pois pude, ao longo deles, enxergar de que forma o livro dialoga com outros livros produzidos pelo Ocidente, seja como influenciado ou influenciador. Isto posto, chegamos ao terceiro e último capítulo, consequência dos dois primeiros. As análises nos mostram as dificuldades que Lalo elenca para que os portorriquenhos sejam lidos como tal, como produtores de seus próprios discursos. Não obstante, o autor não só menciona como tenta superar essas adversidades, escrevendo um texto que produz uma teoria que conecta "invisibilidade" e Ocidente. Para tal, utiliza o gênero ensaio, tão emblemático na América Latina se consideramos, por exemplo, seu extenso uso em textos que versam sobre identidade ao longo do século XIX, século das independências e formação dos Estados Nacionais, e do XX. O capítulo final relaciona a escolha do gênero com a temática de Lalo e estabelece que tipo de espaço nacional o autor criou.

Para os que estão tão inseridos em uma "lógica ocidental", em um jogo de representações cujas regras foram estipuladas pelo Ocidente, custa ler os portorriquenhos como produtores de seus próprios discursos. Acredito que o presente trabalho traz à tona questões pertinentes sobre a puertorriqueñidad, sobre nacionalismos e sobre identidade. 


\title{
CAPÍTULO I - O MAR, A ÁGUA, AS ILHAS
}

\author{
"El mar es lo que (se) siente. La mar se lleva en el cuerpo" \\ Juan Carlos Quintero Herencia \\ La hoja de mar (:) Efecto archipiélago I
}

Los países invisibles, livro de ensaios escrito pelo portorriquenho Eduardo Lalo em 2008, consta de três partes: "El viaje", "La carretera número 3" e "El experimento". A primeira parte consiste no relato de uma viagem que Lalo fez para Europa em 2005 como tutor de um grupo de estudantes portorriquenhos. Na ocasião, esteve em Londres, Veneza, Madri e Valença. Cada cidade gerou um relato particular que começa com um cabeçalho indicando local e data de escritura, aproximando-se, assim, de um diário de viagem. A segunda parte, a mais curta do livro, é a narração da viagem de volta da Europa à Porto Rico. Lalo descreve desde as imagens de Porto Rico vistas do alto, enquanto estava no avião, até o deslocamento terrestre realizado na própria ilha pela "carretera número 3", segunda maior estrada portorriquenha. Esta parte do livro apresenta uma mudança em relação a primeira. Enquanto em "El viaje" a escrita é colocada em evidência, a leitura ocupa um papel principal a partir de "La carretera número 3" e seguirá sendo a protagonista em "El experimento". Nesta última parte, o autor comenta o experimento de não comprar mais livros, mas de mergulhar em sua biblioteca particular, explorando os livros que possui. Isso ocorre unicamente em Porto Rico e os deslocamentos do autor são internos, priorizando o cenário da capital, San Juan.

Este capítulo se debruçará sobre as imagens aquáticas presentes no ensaio, que perpassam as três partes do livro - não à toa utilizamos, por exemplo, o verbo "mergulhar" para referir-nos à viagem de Lalo em "El experimento". Buscamos encontrar, através dessas imagens, o "efeito arquipélago" presente nessa escrita, como apresentado por Juan Carlos Quintero Herencia no livro La hoja de mar (:) Efecto archipiélago I. Para o autor, "arquipélago" é um modo de exposição do corpo para os efeitos do mar na terra, do corpo da terra ante e sobre os efeitos do mar ${ }^{1}$. O que se propõe, e que tentaremos seguir neste capítulo, é inverter o foco da pequenez

\footnotetext{
${ }^{1}$ HERENCIA, Juan Carlos Quintero. La hoja de mar (:) Efecto archipiélago I. Leiden: Almenara, 2016, p. 16.
} 
territorial de uma ilha para a imensidão de água que a rodeia. Nas palavras de Herencia: "el efecto archipiélago es ante todo una experiencia que hace posible el lenguaje, que antecede, en este caso, lo literario desatándolo en la medida que entrega una temporalidad caribe para un imaginario corporal como histórico"2. Dessa forma, a existência de um corpo em um arquipélago é o que antecede o literário e possibilita a linguagem. Ainda com o mesmo autor: "de lo que trata es de imaginar ideas en torno a la corporalidad, el saber político y a la escucha. En fin, desearle otras imágenes al sensorium que gusta de activarse por este archipiélago"3. Este sensorium ativado pelo efeito arquipélago consiste nas experiências vividas por um sujeito. $O$ livro se propõe a desnaturalizar o que comumente é entendido como caribenho, que por si só consiste em uma interpretação do Caribe, e mostrar a brecha, o que fica entre essa vivência e as interpretações pré-existentes dela. Quintero Herencia escreve:

"El sensorio, la materialización física de una actualidad perceptiva, de un estar entre ( ) las islas puede nombrarse como archipelágico en la medida que el sensorio que afecta no es, sino que sucede en las impresiones desatadas sobre sus sentidos. [...] Así este archipiélago es más un evento estético, una relación con las fluctuaciones y vaivenes de la corrosión marina en su paso por el mundo, que una zona geográfica o alguna identidad identificable en algún mapa. De aquí que, en tanto evento perceptivo, inscrito en textos y formas, insista en aparecer desde avatares del desconcierto, la retirada, el daño o la pérdida [...]. El archipiélago, como fenómeno de la sensorialidad humana, se percibe mejor como el trazo de alguna forma de existir, de vivir, [...]; el texto, la voz o el cuerpo que lo percibe es la relación misma que lo hace sensible, que le da cuerpo y materia a sus imágenes"4

A partir dessa citação, podemos delinear o que faremos neste capítulo. Buscaremos o efeito arquipélago em Los Países Invisibles, considerando-o como um efeito das águas do mar na vivência que Lalo expõe em seu ensaio. Esse efeito se percebe na própria escrita do autor portorriquenho, na voz que transforma suas vivências em discurso, que cria imagens e representações.

No verbete "Insularidade", escrito por Elena Palmero González para o compilado Viagens, deslocamentos, espaços: conceitos críticos, a autora afirma que a literatura caribenha possui, em seu ensaio de reflexões identitárias, associações

\footnotetext{
2 Ibidem, p. 17. , p. 20. pp. $35-36$.
} 
fortes às noções de insularidade, arquipélago e meta-arquipélago. As três são mobilizadas aqui, através do citado Quintero Herencia, de Antonio Pedreira, de José Lezama Lima e de Antonio Benítez Rojo. Colocamos um acento na imagem da flutuação, visto que "como a ilha delimita um espaço de terra suspenso no meio aquático, pensar o insular propõe também pensar no mar"5.

\subsection{A visibilidade enquanto condição}

Como mencionado anteriormente, a primeira parte do ensaio consiste em um diário de viagens de Lalo pela Europa como tutor de um grupo de estudantes portorriquenhos. Nos inteiramos que não se trata da primeira visita dele ao antigo continente, conforme se delineiam comparações entre as duas viagens. Na viagem durante a qual se produz esse diário, o autor visita Londres, Veneza, Madri e Valença.

Em Londres, o autor nos conta sobre sua visita ao cemitério Highgate. Em Veneza, no meio de sua narração sobre os passeios que fez na cidade, desenvolve o conceito de "hipervisibilidade". Em Madri, onde vivera alguns anos antes da presente viagem, descobrimos semelhanças e diferenças possíveis entre San Juan e a capital da Espanha. Por fim, quando chega em Valença, a identificação com sua itha caribenha é completa. As viagens estão conectadas através do tema da invisibilidade e suas variações.

Em Londres, em sua visita ao cemitério, o autor se depara com turistas cujo único interesse era ver o túmulo de Karl Marx. Eles haviam viajado com uma imagem fixa e definida desse ponto turístico, provavelmente gerada por pesquisas anteriores realizadas na internet ou por guias turísticos, e buscavam unicamente encontrar um correspondente na realidade de uma imagem virtual formulada. Portanto, quando chegavam ao túmulo que procuravam, tiravam muitas fotos e iam embora.

No segundo destino, Veneza, Lalo descreve a cidade como um espaço feito para turistas e que, consequentemente, tornou-se cópia de sua cópia. Quando alguém viaja para Veneza, possui previamente fixado o que busca: as máscaras, o carnaval, os canais. O fenômeno do túmulo de Marx se expande por toda a cidade. Por isso, Veneza se reconstruiu em função do que os turistas esperam dela. $O$ autor nomeia este fenômeno "hipervisibilidade" e escreve que "Venecia se ha convertido en

\footnotetext{
${ }^{5}$ GONZÁLEZ, Elena Palmero. Insularidade. In: COSER, Stelamaris (Org). Viagens, deslocamentos, espaços:
} conceitos críticos. Vitória: EDUFES, 2016, p. 187. 
tautología, en una monumental construcción que certifica, más allá de toda duda, que las imágenes de la ciudad que se han esparcido por el mundo no son virtuales, sino que poseen la autenticidad del original convertido en copia de su copia"6. Segundo o autor, a hipervisibilidade e a invisibilidade são um par, pois tanto o excesso quanto a falta de olhares, de imagens e de discursos sobre uma cidade resultam na condição de invisível.

Em uma entrevista à revista Cuadernos hispanoamericanos ${ }^{7}$, Eduardo Lalo comenta que a (in)visibilidade é um mecanismo sofisticado de dominação. A condição de visibilidade constrói curiosidade e determina o prestígio dos espaços, sendo, também, uma política de circulação de textos. No caso de Veneza, os nativos não conseguem viver sua nacionalidade porque vivem uma cópia das imagens virtuais textos - desenvolvidas por outros. As imagens geradas quando alguém pensa ou vai para Veneza são as turísticas. Os venezianos seriam, em última instância, tão invisíveis quanto os portorriquenhos, ainda que Veneza seja uma potência turística. Os que vivem em Porto Rico padecem da invisibilidade porque o adjetivo pátrio "portorriquenho" é um significante vazio. A identidade portorriquenha não traz nenhuma imagem para o interlocutor, ou seja, não significa nada para quem pensa nela: é invisível.

Neste ponto, é importante estabelecermos conceitualmente o que entendemos por identidade e por identidade nacional para compreendermos a que grupo nos referimos quando mencionamos, por exemplo, "venezianos" ou "portorriquenhos". Neste trabalho, adotaremos a visão de Stuart Hall sobre o tema, desenvolvida fundamentalmente no livro $A$ identidade cultural na pós-modernidade.

Hall apresenta três concepções de identidade, protagonizadas por três sujeitos distintos. A primeira é o sujeito do iluminismo. O centro desse sujeito, o centro do eu, era sua própria identidade, a qual emergia logo no nascimento do indivíduo, não estabelecendo nenhuma relação com o exterior ou com outros indivíduos. A segunda é a do sujeito sociológico, aquele cujo núcleo interior formava-se na relação com outras pessoas importantes para ele, as quais mediavam os valores, sentidos e símbolos - a cultura - dos mundos que ele habitava. A função da identidade era a de

\footnotetext{
${ }^{6}$ LALO, Eduardo. Los países invisibles. Madrid: Fórcola Ediciones, 2016, p. 17.

7 “Entrevista a Eduardo Lalo", in Cuadernos hispanoamericanos, no 799, Janeiro/2017, p. 94-107.
} 
costurar o sujeito à estrutura, ambos unificados e passíveis de predição. A terceira concepção é a do sujeito pós-moderno. Para ele, a identidade é caracterizada como “celebração móvel”. Em outras palavras, este sujeito está sempre em mutação, formado e transformado continuamente pelas formas que o representam ou interpelam nos sistemas culturais ao seu redor. Uma vez que a identidade muda de acordo com a forma como o sujeito é interpelado ou representado, a identificação pode ser ganhada ou perdida. Ela tornou-se, em outras palavras, politizada.

Posteriormente, Hall mostra como este "sujeito fragmentado", o sujeito pósmoderno, é colocado em termos de suas identidades culturais (particularmente a identidade nacional). $\mathrm{O}$ autor começa determinando que as identidades nacionais não são coisas com as quais nascemos, mas são formadas e transformadas no interior da representação. A nação deixa de ser uma entidade política ${ }^{8}$ e torna-se algo que produz sentidos - um sistema de representação cultural. Uma nação é uma comunidade simbólica e isso explica seu "poder para gerar um sentimento de identidade e lealdade" nos sujeitos. Portanto, as culturas nacionais não são compostas apenas por instituições culturais, mas também por símbolos e representações. Uma cultura nacional é um discurso - um modo de construir sentidos - que influencia e organiza tanto nossas ações quanto a concepção que temos de nós mesmos. As culturas nacionais, ao produzirem sentidos sobre a "nação", sentidos com os quais podemos nos identificar, constroem identidades. Para essa categoria, uma cultura nacional busca unificar os sujeitos numa identidade cultural e representá-los como uma grande família nacional.

Adotamos, assim, a concepção de que identidade nacional é um discurso construído sobre um grupo de pessoas, o qual visa organizar as ações e percepções deste grupo. As condições de visibilidade, a hipervisibilidade e a invisibilidade postuladas por Eduardo Lalo compõem-se, portanto, por instituições culturais, símbolos e representações. Na entrevista já mencionada para Cuadernos Hispanoamericanos, Lalo exemplifica a invisibilidade com o seguinte caso:

"Los enunciados "filósofo francés" y "filósofo puertorriqueño" son lingüísticamente idénticos. El primero, aparte de ofrecer la ilusión de lo

\footnotetext{
${ }^{8}$ As nações deixam de ser comunidades limitadas e soberanas, como determinou Benedict Anderson.
} 
"natural", brinda el realce de una denominación de origen, mientras que el segundo puede interpretarse como chiste" ${ }^{\text {" }}$.

A ilusão de naturalidade gerada pelo enunciado "filósofo francês" é decorrente das grandes quantidades de discursos e representações gerados sobre este enunciado, ao passo que "filósofo portorriquenho" não produz nenhuma imagem para o interlocutor, ou seja, não significa nada para quem enuncia essas palavras. Este seria um exemplo de invisibilidade: a ausência de discursos e representações derivadas do adjetivo "portorriquenho". No caso de Veneza, por outro lado, a cidade enquanto polo turístico produz representações que os turistas usam para defini-la, sublimando qualquer outro traço que os venezianos, enquanto sujeitos pós-modernos, poderiam possuir para definir-se. Logo, a cidade é invisível devido ao excesso de discursos que se relacionam à identidade veneziana.

\subsection{Terrorismo: a revolta do invisível}

Ainda em Veneza, Eduardo Lalo compartilha com seus leitores algumas reflexões sobre o terrorismo. Enquanto estava na Europa, ocorreram alguns ataques terroristas em Londres, cidade que ocupava um lugar privilegiado nos meios de comunicação por conta de uma reunião dos líderes do G8 naqueles dias. O escritor relaciona o terrorismo com a busca por visibilidade. Para ele, o terrorista procura um meio de tornar-se visível em um mundo ocidental que o invisibilizou. Segundo o autor "lo que se busca es la mediatización de la víctima"10. Para comentar esta afirmação, é necessário revisitar alguns episódios da história do Partido Nacionalista de Porto Rico e, posteriormente, mobilizar a reflexão do ensaísta René Marqués sobre o tema.

Em 1898, ao perder a guerra de independência de Cuba para os Estados Unidos, a Espanha cedeu Porto Rico, Filipinas e a ilha de Guam aos estadunidenses como indenização. A entrada dos estadunidenses significou que, em relação à soberania, a ilha continuou com o status oficial de colônia até 1952, quando lhe foi atribuído o status de Estado Livre Associado (ELA) ${ }^{11}$.

\footnotetext{
9 "Entrevista a Eduardo Lalo", in Cuadernos hispanoamericanos, n 799, Janeiro/2017, p. 97.

${ }^{10}$ LALO, Eduardo. Los países invisibles. Madrid: Fórcola Ediciones, 2016, p. 22.

${ }^{11} \mathrm{Em}$ Porto Rico existem três opções de status, as quais são constantemente votadas em referendos sem valor oficial para o governo norte-americano, apenas como plebiscitos para consultar a opinião populacional. A primeira é uma posição política a favor do anexionismo, ou seja, tornar a ilha o quinquagésimo primeiro estado da União norte-americana. A isso chamam estatidad. Outra posição é a favor da independência, para que Porto Rico se torne um país autônomo. Por fim, existe a possibilidade do Estado Livre Associado (ELA), em vigor até
} 
No que diz respeito às movimentações políticas de dentro da ilha frente às mudanças, nos interessa comentar a atuação do Partido Nacionalista. Criado em 1922, o partido teve, até 1930, caráter de associação de intelectuais e profissionais liberais preocupados com a preservação da cultura portorriquenha (e sua raiz hispânica) contra a "amerizanização" estadunidense ${ }^{12}$. Em 11 de maio de 1930, Pedro Albizu Campos foi eleito presidente do partido e, a partir de então, adotou uma posição anti-imperialista tanto no discurso quanto na prática.

A declaração de invalidação dos plebiscitos ordenados pelo Congresso dos Estados Unidos acompanhou a opção pela ação armada. Esta consistiu na criação de um "Exército Libertador" e na obrigatoriedade do serviço militar para todos os membros do partido. A militarização foi seguida de diversos atentados realizados pelo grupo, cujo objetivo principal era chamar a atenção da opinião pública internacional "la mediatización de la víctima" ${ }^{3}$, nas palavras de Eduardo Lalo - para a situação colonial de Porto Rico. Um dos atentados mais famosos dessa série foi o assalto ao Congresso dos Estados Unidos em 1 de março de 1954, quando nacionalistas abriram fogo contra membros do congresso a partir da galeria de visitantes. A ação foi repreendida e alguns participantes foram presos. A meta era protestar contra o Estado Livre Associado e a falsa declaração dos Estados Unidos de que Porto Rico deixara de ser colônia pois, como vimos anteriormente, o status de ELA não afetou diretamente na autonomia da ilha.

Apesar do fracasso do Partido Nacionalista nas eleições e nos atentados, sua existência obrigou os demais partidos a se posicionarem frente ao status de ELA e à

\footnotetext{
hoje. Esse status foi inaugurado em 25 de julho de 1952 e, segundo Kátia Baggio, "A Constituição que criou o "Estado Livre Associado de Porto Rico" ocupou-se basicamente dos assuntos relacionados ao governo local, deixando para a Lei de Relações Federais a regulamentação das relações entre Porto Rico e os Estados Unidos. O ELA não rompeu, portanto, com a situação colonial, [...]" (BÁGGIO, 1998:41). Sobre a implantação do ELA e alguns de seus impactos na realidade portorriquenha, ainda com Kátia Baggio, temos que

“O novo status jurídico-político possibilitou uma maior autonomia na administração dos problemas locais, mas não rompeu com a condição colonial. Porto Rico não conseguiu constituir-se em um Estado Nacional soberano. A questão do status é central no debate político porto-riquenho, pois sua definição é essencial para a resolução de qualquer projeto para o país, que deve passar necessariamente por uma das três vias que se apresentam no cenário político: a transformação de Porto Rico em mais um estado - o quinquagésimo primeiro - da União norte-americana (estatidad), a manutenção do Estado Livre Associado ou a independência. Pensar no futuro de Porto Rico, portanto, é pensar no problema nacional" (BAGGIO, 1998: 16-17).

12 BAGGIO, Kátia G. A questão nacional de Porto Rico: o Partido Nacionalista (1922-1954). São Paulo: FAPESP: Annablume, 1998, p. 27.

${ }^{13}$ LALO, Eduardo. Los países invisibles. Madrid: Fórcola Ediciones, 2016, p. 22.
} 
situação colonial da ilha. Não apenas os partidos, mas os ensaístas também o fizeram. René Marqués o faz no ensaio "El puertorriqueño dócil (Literatura y realidad psicológica)", publicado em 1960. O ensaio faz parte do livro Ensayos (1953-1966), que contem dez textos nos quais se evidencia a preocupação do autor pelo destino de Porto Rico. O epílogo da coletânea é composto por três citações que postulam a unidade temática do livro: a vida e o ser portorriquenho. Somado a isso, o livro é explicitamente dedicado à juventude daquela ilha.

O ensaio "El puertorriqueño dócil" afirma que os portorriquenhos são dóceis. Em seguida, Marqués nos apresenta a definição de docilidade que adotará ao longo do texto: "[...] es carecer de fuerza y aun voluntad para oponer resistencia a lo que los demás exigen, insinúan o mandan: cierta propensión a obedecer, a seguir el ejemplo, la opinión, el consejo de los otros [...]"14. O objetivo do texto é comprovar a existência dessa característica na população portorriquenha daquele momento. Para isso, Marqués escolhe a literatura contemporânea à escrita do ensaio como objeto de análise, alegando que esse meio de expressão reflete a sociedade em que é produzido ${ }^{15}$.

Inicialmente, os portorriquenhos foram caracterizados como "aplatanados" e "ñangotados". Estes foram substituídos por "fatalistas" e "resignados", alcançando, por fim, a designação de "pacíficos" e "tolerantes". Todas essas definições estariam sendo empregadas para fazer referência à docilidade mencionada anteriormente. Marqués parte do ensaio de Antonio S. Pedreira, Insularismo (1934), para ver como o fenômeno do aplatanamiento ${ }^{16}$ ainda se dava no portorriquenho e afirma que o último sinônimo

\footnotetext{
${ }^{14}$ MARQUÉS, René. Ensayos (1953 - 1966). Barcelona: Editorial Antillana, 1966, pp. 149 - 150.

${ }^{15}$ A visão realista da literatura também está em outros ensaios da coletânea em que El puertorriqueño dócil está inserido. Em "Un autor, un intríngulis y una obra”, por exemplo, René Marqués comenta a obra La Muerte, de Emilio S. Belaval, como um produto do período em que foi escrita: "De este período de desquiciamento espiritual en lo nacional y de eliminar la tragédia en lo universal es produto La Muerte" (MARQUÉS, 1966: 20). O mesmo se dá em "Pesimismo literario y optimismo político: su coexistencia en el Puerto Rico actual", cujo objetivo do texto é "limitaremos el intento de análisis a la producción literaria misma y a su relación, directa o indirecta, con el acontecer político contemporáneo, ciñéndolo, además, como lo anticipa el título, a la literatura y la política puertorriqueñas de los últimos veinte años" (MARQUÉS, 1966: 27).

${ }^{16}$ Para Pedreira, os portorriquenhos estariam em permanente angústia aguardando o verão, as tormentas e os terremotos. A irregularidade climática da ilha, ou seja, quando as tormentas e terremotos não ocorriam, ocasionava uma reflexão dos que lá vivem a respeito do fracasso que os rodeava. A consequência final desse processo constante de espera, decepção e fracasso, era a adoção de uma atitude derrotista e acomodada. Segundo o autor: "El clima nos derrite la voluntad y causa en nuestra psicología rápidos deterioros. El calor nos madura antes de tempo y antes de tempo también nos descompone. De su enervante presión sobre los hombres viene esa característica nacional que llamamos el aplatanamiento. Aplatanarse, en nuestro país, es una especie
} 
encontrado para referir-se à mesma característica foi "democrático". Esse termo é descrito como uma droga que faz o homem dócil aceitar, sem resistência, sua docilidade. É como se a palavra "democrático" suavizasse a docilidade e, por não ser tão ofensiva quanto os adjetivos anteriores, ninguém se rebelasse contra ela.

Ao comentar a guerra da Coreia e o desempenho dos soldados portorriquenhos que integraram o exército estadunidense no combate, o ensaísta enfatiza o elevado número de soldados mortos provenientes da ilha. Algo semelhante se dá, segundo o texto, na literatura. Para René "un examen superficial o frívolo de la literatura actual en Puerto Rico haría pensar al lector no avisado que se trata de la expresión de un pueblo agresivo. Ello, por la cantidad de violencia física en nuestra literatura"17. Portanto, haveria um paradoxo, dado que aos portorriquenhos sempre lhes foi atribuída a característica de dóceis. A explicação disso é uma das teses sustentadas pelo autor:

"Los actos violentos de los personajes literarios - y abundan éstos en todos los géneros en prosa - no son, en último análisis, producto de una doctrina revolucionaria, de una tradición heroica, de una rebeldía consciente y luminosa o de una agresividad normal y saludable, sino más bien de la desesperación de seres débiles y dóciles acorralados en el último reducto de la dignidad humana"18

Conclui-se, então, que a violência dos portorriquenhos, nos personagens e na guerra da Coreia, não decorre do desejo de matar o outro, mas de morrer, de matar a si mesmo. O que existe dentro dos portorriquenhos é definido como um impulso auto destrutor, como uma "tendência suicida". Justamente por serem dóceis e não se rebelarem contra o status colonial da ilha, as pessoas desistem de lutar e decidem acabar com as próprias vidas.

Para Marqués, o fracasso dos atentados nacionalistas denota o caráter autodestrutivo do cidadão portorriquenho. Como os atentados sempre falhavam e possuíam uma considerável quantidade de militantes nacionalistas mortos, ele

\footnotetext{
de inhibición, de modorra mental y ausencia de acometividad. Es seguir, sin sofocarse, cómoda y rutinariamente, el curso de la vida, sin cambios ni inquietudes, cabeceando nuestras aspiraciones y en cuclillas frente al porvenir" (PEDREIRA, 2001: 57). Este mal-estar com o clima se estendia à paisagem. Porto Rico é definido como uma ilha com vegetação de caráter majoritariamente feminino e, logo, passivo. O fatalismo geográfico - Porto Rico é a ilha de menor espaço físico dentro das Grandes Antilhas - é igualmente apontado como uma das causas geradoras da personalidade "aplatanada", sem inquietudes e aspirações para o futuro, dos que lá viviam.

${ }^{17}$ MARQUÉS, René. Ensayos (1953 - 1966). Barcelona: Editorial Antillana, 1966, p. 151.

18 Ibidem, p. 156.
} 
defende que o objetivo real não era matar nem vencer, mas morrer. Os militantes almejavam, portanto, o suicídio, reiterando a docilidade do povo. Em outras palavras, os militantes desistiam de lutar e, por isso, decidiam morrer. Não existiria, para este autor, um contraponto entre os anexionistas e os nacionalistas: ambos são igualmente suicidas. Enquanto estes buscavam uma morte física, aqueles desejavam uma morte moral e espiritual ao atacar sua essência portorriquenha. René Marqués escreve:

"Tan suicida es el gesto del nacionalista que, para provocar su muerte física ataca la Casa Blair, como el del anexionista que, para provocar su muerte moral y espiritual, ataca con intención destructora, su propia esencia puertorriqueña. Ideológicamente aparecen ambos como antípodas, pero psicológicamente son almas puertorriqueñas gemelas"19

O impulso autodestrutivo une posições políticas que pareceriam opostas. Entretanto, há uma diferença: o nacionalista consegue a morte física, ao passo que o anexionista é um eterno condenado à autodestruição, sem conseguir alcançar seu objetivo nunca. Marqués comenta um caso em que o impulso suicida alcança um dos mais altos níveis: as pessoas negras anexionistas. Esta parte da população estaria abdicando de uma vida sem racismo para ingressar em uma cultura exterior na qual o preconceito contra o negro possuiria níveis de ódio, crueldade e selvageria muito maiores que em Porto Rico. A explicação desse outro paradoxo - o negro que quer sair de uma ilha sem racismo para morar em um país racista onde o risco de morrer seria muito maior - residiria em questões biológicas e psicológicas, coincidentes entre os negros e políticos anexionistas. Para Marqués, há um mecanismo que atrofia algumas partes do cérebro e reduz o poder racional de associação, desenvolvendo uma incapacidade - conveniente para esses sujeitos - de associar situações, acontecimentos e ideias. Nomeado “block psicológico”, é um traço típico do portorriquenho dócil daquela época.

O estadolibrismo, o status de ELA, é lido como a síntese da docilidade portorriquenha. O autor escreve que esta invenção política é

"genial [...] por haber logrado cuajar en forma casi doctrinaria la realidad psicológica del pueblo que le da razón de ser. Es, en efecto, el Estado Libre Asociado expresión auténtica de la componenda, encarnación del eufemismo, 
producto acabado del arte espurio de dorar la píldora; en otras palabras, síntesis psicológica del hombre tímido y dócil"20

O Estado Livre Associado só poderia existir em Porto Rico, por conseguir naturalizar a condição colonial e mascará-la sob o adjetivo "democrático". Dessa forma, não gerou nenhuma reação ou luta populacional. A revolta estaria apenas no plano da literatura, através das tramas criadas por escritores que se revoltaram com esta condição. No âmbito das mobilizações populares, nada aconteceu e a população se acomodou sob esse status, reafirmando sua docilidade.

Toda essa discussão histórica e ensaística é o plano de comparação de Eduardo Lalo ao comentar os ataques de Londres. Para Lalo, o objetivo real do terrorismo é alcançar a visibilidade do Ocidente. Quando menciona os atentados terroristas ocorridos na Europa durante sua viagem, o contraponto é o caso portorriquenho. A partir daí provem uma reflexão sobre a invisibilidade, a qual se torna verídica quando um país sofre uma intervenção "por el discurso del Otro y Éste habló y habla por ellos" ${ }^{21}$. Os sujeitos não optam pela invisibilidade, mas sofrem esta condição imposta pelos que escrevem a história dos invisíveis, eliminando a possibilidade de que estes o façam por si próprios. O que, para René, é uma característica inerente ao portorriquenho, a docilidade, para Lalo é consequência das imposições discursivas dos grupos hegemônicos. Ambos coincidem no que concerne ao impulso suicida e ao desejo de morrer enquanto estratégia para chamar a atenção. Entretanto, para Marqués, este é consequência da docilidade, enquanto para Lalo, é uma estratégia de resistência.

\subsection{A construção de uma perspectiva}

Pouco a pouco, Lalo mistura as experiências vividas no continente Europeu com os debates sobre a invisibilidade de sua ilha através de sua perspectiva singular. Seguindo sua viagem, o próximo destino é Madri. Na capital da Espanha, Lalo relata como é a sensação de ter acesso a tudo. Lá, nas lojas e supermercados, era possível ter acesso a tudo que é visível, porque há uma parte da população que consome estes produtos. Esse é um dos benefícios da condição de visibilidade e o turista que vem de um país invisível sabe que é necessário aproveitar esta oferta. O que lhe resta

20 p. 170.

${ }^{21}$ LALO, Eduardo. Los países invisibles. Madrid: Fórcola Ediciones, 2016, p. 26. 
depois dessa experiência é "el dolor sanjuanero, la sensación de fatalidad, de injusticia, de pérdida por toda la vida". Até este momento, ecoa uma melancolia piñeriana. no ensaio de Lalo. Este "dolor sanjuanero" coincide com o valor semântico negativo que Virgilio Piñera atribui à ilha. Recordemos os primeiros versos de seu poema $\mathrm{La}$ isla en peso, em que poeta cubano escreve "La maldita circunstancia del agua por todas partes". Tanto em Lalo quanto em Piñera, há um aprisionamento pela circunstancial maldição aquática do isolamento em uma ilha ${ }^{22}$. Não há combate possível contra a condição islenha. Contudo, a sensação de fatalidade por haver nascido em uma ilha como Porto Rico muda quando o escritor pontua uma diferença entre a viagem narrada em Los países invisibles e uma viagem que fez à Europa anteriormente.

Na primeira viagem de Lalo à Europa, o regresso a San Juan significou uma profunda depressão, acompanhada de questionamentos como: “¿Por qué estoy aqui? ¿Por qué soy obligado a vivir esa condición de invisibilidad?". Por outro lado, depois da segunda viagem, o regresso produz uma sensação distinta. Lalo escreve:

"Creo tener un sólo mérito: el de haber abrazado al infierno [...] que ya aquí no es un país, sino una categoría y haber sobrevivido. Para el que estuvo tan cerca de su propia aniquilación (y cuántos han estado en ese país tan cerca del fin absoluto) ésta es una señal de fuerza [...]. He vuelto diferente, con un poder que no tuve antes: el de haber sobrevivido a una mirada que no me ve"23.

Além de enfatizar novamente a questão da sobrevivência e da aniquilação ou fim absoluto, que dialoga com os pontos levantados por Marqués, esse trecho permite afirmar o que já havíamos proposto anteriormente: o contraponto da viagem de Lalo é San Juan. Ao falar de suas experiências, do que observa e do que acontece, Lalo dialoga diretamente com sua realidade portorriquenha, ainda que, em alguns momentos, não explicite a comparação. Em Londres e Veneza, isso não é evidenciado no texto, porém demonstramos anteriormente como a comparação é elaborada. Já em Madri e Valença, a contraposição é evidenciada e o autor fala cada vez mais de sua ilha de origem. A narração da viagem através de uma perspectiva portorriquenha sai do segundo plano e é desenvolvida explicitamente. O último fragmento que citamos nos mostra que a primeira parte do livro deve ser lida com a consciência de que o que se lê é o relato de um portorriquenho que sobreviveu a um olhar que o

\footnotetext{
22 HERENCIA, Juan Carlos Quintero. La hoja de mar (:) Efecto archipiélago I. Leiden: Almenara, 2016, p. 380.

${ }^{23}$ Ibidem, pp. 59 - 60.
} 
invisibiliza. Na entrevista ao Cuadernos Hispanoamericanos, Lalo declara: "El material de mi trabajo son las circunstancias de mi existencia. Me desplazo, camino, observo. Mi mochila es el estuche de un instrumento que llevo siempre conmigo"24 (grifo nosso). Logo, as circunstâncias de sua existência enquanto portorriquenho estão em todo ensaio.

O ápice das reflexões sobre a invisibilidade ocorre em Valença. Assim como em Porto Rico, os escritores valencianos não se identificam com o espaço nacional e, por isso, entram em um vazio de representação, dado que:

“[...] la confusa balcanización literaria de la península ibérica parece no tener fronteras, pero a la vez sí las tiene, dependiendo de dónde se escriba y en qué idioma se haga. Este reino de lo sui generis, de la voz aberrante, produce evidentes reminiscencias puertorriqueñas y constituye otra forma más en que se disputa por la visibilidad y se impone a otros la invisibilidad"25.

O escritor afirma que, ao longo de sua viagem, pôde se conectar com outras realidades excêntricas e, a partir delas, refletir sobre as possibilidades que sua própria posição oferece. A mais importante delas é desenvolver um olhar, uma perspectiva portorriquenha:

"[...] las posiciones que tantos europeos, estadunidenses e incluso ciertos latinoamericanos asumen ante mí y los que vienen de países invisibles me sirven para construir el material filosófico y literario de mis libros [...]. Se debe crear desde lo que se tiene, desde lo que se es, desde el lugar en el que se le pone a uno [...] negar la mirada del otro; efectuar no una re- sino una contraconquista"26.

A menção à contraconquista traz ecos lezamianos. No ensaio "La curiosidad barroca", Lezama Lima apresenta este conceito como um modo de estar no mundo, um estilo pleno que abrange todas as esferas do ser. ${ }^{27} \mathrm{~A}$ perspectiva sob a qual Lalo escreve encaixa-se nesta categoria, pois é uma maneira de habitar o mundo que lhe

\footnotetext{
24 “Entrevista a Eduardo Lalo”, in Cuadernos hispanoamericanos, no 799, Janeiro/2017, p. 103.

${ }^{25}$ LALO, Eduardo. Los países invisibles. Madrid: Fórcola Ediciones, 2016, p. 41.

${ }^{26}$ Ibidem, p. 52.

27 Nas palabras de Lezama: "Nuestra apreciación del barroco americano estará destinada a precisar: primero, hay una tensión en el barroco; segundo, un plutonismo, fuego originario que rompe los fragmentos y los unifica; tercero, no es un estilo degenerescente, sino plenario, que en España y en la América española representa adquisiciones de lenguaje, tal vez únicas en el mundo, muebles para la vivienda, formas de vida y de curiosidad, misticismo que se ciñe a nuevos módulos para la plegaria, maneras del saboreo y del tratamiento de los manjares, que exhalan un vivir completo, refinado y misterioso, teocrático y ensimismado, errante en la forma y arraigadísimo en sus esencias. Repitiendo la frase de Weisbach, adaptándola al americano, podemos decir que entre nosotros el barroco fue un arte de la contraconquista"(LIMA, 1993: 79-80).
} 
permite desenvolver sua escrita. A partir de seu ponto de vista portorriquenho e de sua "vocación peripatética", consegue postular a invisibilidade como condição e perspectiva, já que estar "[...] fuera del mundo es también una forma de vivir en el mundo". Se, no texto de Lezama, o índio Kondori e Aleijadinho são agentes do barroco que conseguem contraconquistar o tradicional estilo europeu através de seus acréscimos americanos, Lalo contraconquista a invisibilidade que lhe impuseram, devolvendo-a como perspectiva de sua escrita.

A condição que fomenta e possibilita a escrita de Eduardo Lalo gera um paradoxo. Por um lado, há um discurso que provém de um sistema de símbolos e representações e que invisibiliza os portorriquenhos. De acordo com o que discorremos até agora, a invisibilidade se dá através da imposição desses símbolos e representações por meio do discurso hegemônico, sem que os sujeitos possam produzi-los sobre si próprios. Essa condição não é uma opção dos que a sofrem, mas possui caráter prescritivo por parte dos agentes produtores, o Ocidente. Por outro lado, essa condição de invisibilidade lhe permite uma perspectiva que é propiciadora de sua escrita. O contraponto com sua realidade é o que fomenta toda a primeira parte de Los países invisibles. Os episódios narrados servem para que o autor possa desenvolver sua ideia de invisibilidade e, também, a aplicação deste conceito ao caso de Porto Rico.

Há, por exemplo, um episódio em que Lalo vai ao lançamento de um livro e, após o evento, conversa com o escritor. Tudo parece bem até mencionar que é portorriquenho. A partir desse momento, sente que seu interlocutor já não o escuta nem o vê. Ele deixa de ser um sujeito para tornar-se um sujeito portorriquenho e isso, de acordo com os discursos hegemônicos impostos, não significa nada. Lalo escreve:

"Antes de abandonar el cóctel, me presentan al Comisario del Libro. Me mira sonriente mientras me da la mano y escucha mi nombre y el lugar del que precedo. Sin embargo, algo ocurre cuando se llega ao segundo dato. Ya no ve ni escucha. [...] porque en pocas ocasiones he sentido, si bien esta escena se ha repetido en mi vida hasta el punto de producir insensibilidad, tal celeridad en la intención, que me transforma en un ser invisible. [...] El prejuicio y la geopolítica cultural funcionan de esta manera. Hay autores y autores. Lo que quiere decir en la práctica que hay nombres de los que no se sabe nada, pero que están unidos al prestigio de una urbe entronizada en las historias literarias y otros que permanecen condenados al sinsentido de pretender la práctica de la escritura en un no canon's land. El comisario, cuando se reúna en el bar con los amigos, podrá hacer un chiste: "Conocí hoy a un escritor puertorriqueño." 
[...] Las posiciones que tantos europeos, estadunidenses e incluso ciertos latinoamericanos asumen ante mí y los que vienen de países invisibles, me sirven para construir el material literario y filosófico de mis libros. [...] Se debe crear desde lo que se tiene, desde lo que se es, desde el lugar en el que se le pone a uno"28

Mobilizamos o longo excerto anterior porque trata de um episódio central para compreender o dispositivo que gera a escrita de Lalo ao longo do ensaio. Se, por um lado, o adjetivo "portorriquenho" é o que o torna invisível, é justamente essa invisibilidade que constrói o material de seus livros.

Se a invisibilidade é uma condição que resulta da ausência da produção de símbolos, representações, textos e discursos sobre os invisíveis, como Lalo consegue transformá-la em força motriz da escrita de seu livro? Para entender como se dá essa operação, mobilizamos um trecho de La isla que se repite, de Antonio Benítez Rojo, no qual o ensaísta cubano reflete acerca das consequências da condição insular caribenha:

"Los antillanos, por ejemplo, suelen deambular por todo el mundo en busca de centros de su "caribeñidad", constituyendo uno de los flujos migratorios más notables de nuestro siglo. La insularidad de los antillanos no nos impele al aislamiento, sino al contrario, al viaje, a la exploración, a búsqueda de rutas fluviales y marítimas"29

Logo, a viagem de Lalo produziu o que ele mesmo chamou de "reminiscencias puertorriqueñas", que Ihe possibilitaram encontrar, na Europa, problemas de visibilidade semelhantes aos que vive em Porto Rico. A projeção do escritor caribenho para fora - Europa - não é realizada com o intuito de afastar-se de sua ilha, mas de encontrar em outro continente as mencionadas reminiscências, sua "caribeñidad". Se a invisibilidade lhe dá matéria - conteúdo - para a construção de seus textos, a viagem é o molde, é como essa matéria será escrita e relatada para os leitores, a partir de uma perspectiva insular. Ao citar François Hartog na terceira parte do livro, o ensaísta confirma nossa análise: "Por eso lo que nos importa no es el viaje en sí mismo, en su materialidad, sino como operador discursivo y esquema narrativo: el viaje como mirada y resolución de un problema o respuesta a una pregunta"30. A viagem como mirada, como perspectiva.

\footnotetext{
${ }^{28}$ LALO, Eduardo. Los países invisibles. Madrid: Fórcola Ediciones, 2016, pp. 51- 52.

${ }^{29}$ ROJO, Antonio Benítez. La isla que se repite. Hanover: Ediciones del Norte, p. xxxii.

${ }^{30}$ LALO, Eduardo. Los países invisibles. Madrid: Fórcola Ediciones, 2016, p. 113.
} 


\subsection{Insularismo cosmopolita}

A correlação constante entre a análise apresentada do ensaio de Lalo e outros ensaístas portorriquenhos demonstra um esforço duplo do autor. Primeiramente, ele estabelece uma tradição para o ensaísmo de sua ilha, na qual se inserem, como vimos, René Marqués, Antonio Pedreira, Pedro Albizu Campos e, como verificaremos posteriormente, José Luiz González. Somado a isso, seu próprio livro dialoga com os ensaios mencionados. Frente a um discurso que insiste em apagar a tradição de territórios invisíveis como Porto Rico, Eduardo Lalo mostra que ela existe e que segue reverberando.

Tratar da condição insular ao estudar Porto Rico remete ao já mencionado Insularismo. Ensayos de interpretación puertorriqueña de Antonio Pedreira. Este livro nos interessa por duas vertentes. A primeira é o formato em que é escrito, no que tange à divisão e à nomeação dos capítulos. A segunda é em relação ao conceito que o autor oferece para identidade em geral e aos argumentos que elabora para justificar suas postulações sobre a identidade portorriquenha em particular.

O livro é dividido em capítulos intitulados "I - La brújula del tema", "II - Biología, geografía y alma", "III - El rumbo de la historia", "IV - Viejas y nuevas taras" e "V - La luz de la esperanza". Ao começar indicando estar em poder de uma bússola, o ensaísta atribui um tom ao livro. Pedreira é o intelectual em poder da bússola que pode guiar os leitores na direção correta, cujas coordenadas serão dadas ao longo da obra. Se nos atentamos, por exemplo, aos subtítulos pertencentes ao capítulo III, temos: "1. Levando el ancla", "2. Buscando el puerto" e "3. Intermezzo: una nave al garete". Essa é a narração do percurso de uma viagem que começa ao levantar a âncora para então ir em busca do porto e, por fim, entrar em deriva. O rumo da história ("III - El rumbo de la historia") é, portanto, uma viagem pelo mar, comandada pelo intelectual em poder da bússola. $O$ tesouro a ser encontrado é a formação de uma juventude consciente e capaz de mudar o rumo de Porto Rico nessa viagem pela história, conforme se lê no último subcapítulo do livro, nomeado "Juventud, divino tesoro". A viagem pode ser bem-sucedida se as instruções do comandante forem executadas eficazmente pela tripulação portorriquenha a bordo da ilha-barco. Sobre isso, Arcadio Díaz Quiñones observa que: 
"El viaje insular - discursivo y paradigmático - le permite mirar con perspectiva de espacio y tempo, abarcar el sentido histórico de la geografía. En esa metáfora, el libro es un navío y la escritura es una aventura. Se trata de una travesía con escalas que permiten perspectivas temporales largas o cortas. [...] el letrado mantiene el rumbo y ordena los relatos secundaros y el principal, como un rompecabezas. Su voz autorizada no permitirá que el lector se pierda; él orienta con su "brújula"”31

Dentro dessa viagem, Pedreira forja seu conceito de identidade e de identidade portorriquenha. $\mathrm{O}$ autor concebe a cultura e a identidade como "[...] peculiar reacción ante las cosas - maneras de entender y de crear - que diferencia en grupos nacionales a la humanidad [...]"32. A construção da cultura em Porto Rico - e consequentemente da identidade, pois ambos coincidem em Pedreira - não teria sido finalizada em decorrência da transição de um conquistador, a Espanha, para outro, os Estados Unidos. O resultado desse processo é a flutuação histórica da cultura portorriquenha entre o gesto hispânico e o anglo-saxão, e a isso o autor denominou "insularismo". Essa flutuação da ilha é a viagem na qual o leitor embarca e na qual os portorriquenhos podem obter êxito se seguirem as coordenadas da bússola em poder do autor. Frente ao insularismo histórico entre Espanha e Estados Unidos, Pedreira defende a retomada do espiritualismo espanhol em preterição do utilitarismo instaurado pelos estadunidenses. Ao final, alega que a personalidade portorriquenha estava em estado transitivo. Portanto, recomendou a formação de uma consciência coletiva que se atentasse para que as transformações se concretizassem corretamente, ou seja, para que houvesse o retorno às raízes hispânicas. Em nenhum momento do livro Pedreira coloca o gesto estadunidense como insuperável. O que se recomenda, ao invés disso, é a manipulação de ambas as culturas. Isso bastaria para a conclusão da formação da identidade portorriquenha.

Duas ideias nos interessam: o formato do livro enquanto viagem e a flutuação. A primeira parte do livro de Lalo é, também, uma viagem. Diferentemente de Pedreira, Lalo não se coloca como possuidor das respostas para as questões históricas que permeiam Porto Rico, embora ambos nos ofereçam uma viagem. A imagem de flutuação da ilha de Porto Rico proposta por Pedreira é reiterada em Los países invisibles. Igualmente em Lalo, é como se a ilha estivesse flutuando pela Europa

\footnotetext{
${ }^{31}$ QUIÑONES, Arcadio Díaz. Sobre los principios: los intelectuales caribeños y la tradición. Bernal: Universidad Nacional de Quilmes, 2006, pp. $353-354$.

32 PEDREIRA, Antonio. Insularismo. Ensayos de interpretación puertorriqueña. San Juan: Editorial Plaza Mayor, 2001, p. 40.
} 
através da perspectiva portorriquenha sob a qual o autor concebe o texto, e essa navegação busca reminiscências nas experiências vividas. A flutuação, a viagem de Porto Rico feita pela Europa através de Eduardo Lalo, permite-Ihe definir a condição de invisibilidade, algo que antes lhe parecia exclusivo, mas que tal viagem demonstrou ser repetida ao redor do mundo. Nomeio esta viagem via flutuação de "insularismo cosmopolita", como uma ilha que boia pelo mundo através da perspectiva de Lalo.

Aqui, começamos a delinear o efeito arquipélago mencionado no início do capítulo. Através da flutuação de Porto Rico pela Europa, representada pelas imagens que o autor nos fornece de sua viagem, gera-se essa perspectiva portorriquenha que, em última instância, impulsiona e possibilita a escrita.

\subsection{1 "Cosmopolita": de que cosmopolitismo estamos falando?}

A ideia de cosmopolitismo na América Latina remonta ao século XIX. De maneira geral, o conceito de cosmopolitismo remonta às pessoas que viajaram por distintos países. Na América hispânica, dois interessantes exemplos devem ser mencionados: Domingo Faustino Sarmiento e Ruben Darío. O primeiro realizou viagens pela América, Europa e África. A influência desses itinerários em sua produção se dá, por exemplo, na elaboração e defesa da teoria de que o que atrasaria a Argentina no alcance do nível de desenvolvimento das colônias anglo-saxônicas especificamente os Estados Unidos - seria a miscigenação de indígenas e negros com o europeu branco. O culpado por isso seria a própria Espanha que, ao permitir a mistura das raças consideradas inferiores com uma raça superior, gerou o atraso de toda a nação. Por outro lado, o poeta Ruben Darío também realizou muitas viagens pelo continente americano e europeu, principalmente em decorrência de seu cargo de diplomata nicaraguense. As influências desses deslocamentos se dão em inovações literárias naquele que é considerado o expoente máximo do modernismo latinoamericano. Nota-se, portanto, que o contato com diferentes partes do mundo pode gerar distintos resultados.

Uma maneira de analisar estes possíveis resultados é através da mobilização de um exemplo brasileiro. Eurídice Figueiredo escreve "Tomando Joaquim Nabuco como epítome do cosmopolitismo latino americano do século XIX, pode-se dizer que ele era sinônimo da alienação de uma elite que tinha os olhos voltados para a Europa 
[...]"33. De certa forma, esta noção tratava de uma elite letrada e rica que viajava para o velho continente com o intuito de trazer as tendências para América Latina em seu regresso. A existência de um sujeito cosmopolita sempre implicou, portanto, na existência de um Outro. O interesse em realizar uma viagem à Europa residia em colocar-se em contato com esse Outro, que no século XIX era tido pelas elites como detentor do verdadeiro saber, e importar sua cultura.

O cosmopolitismo insular de Lalo não dialoga com essa concepção. A viagem de Lalo, inclusive após seu retorno - partes dois e três do ensaio - não demonstra ter como objetivo importar algum tipo de saber europeu. O autor faz o oposto: a viagem o leva a desenvolver uma perspectiva ainda mais particular, que reafirma não só sua nacionalidade portorriquenha como também sua invisibilidade. De nenhuma forma o autor se aliena voltando seus olhos somente para a Europa, pois suas reminiscências portorriquenhas são as que ditam sua escrita. A viagem de Lalo tampouco é um processo migratório, mas um périplo que possui fim e implica em retorno ao território de origem. O ensaio de Lalo e sua teoria da invisibilidade advogam pelo multiculturalismo ${ }^{34}$ que visa incluir a diferença ao invés de tentar apaga-la em uma busca pelo homogêneo.

\section{5 “Um portorriquenho pode ser lido como alguém ou só como um portorriquenho?"}

A primeira parte do ensaio de Lalo, seu diário de viagem, estabelece, portanto, uma forte relação com o mundo, desprendendo-se do que Duchesne Winter denomina

33 FIGUEIREDO, Euridice. Cosmopolitismo. In: COSER, Stelamaris (Org). Viagens, deslocamentos, espaços: conceitos críticos. Vitória: EDUFES, 2016, p. 43.

${ }^{34}$ No texto "O cosmopolitismo do pobre", Silviano Santiago aponta para dois tipos de multiculturalismo, ou seja, de contato entre culturas. O primeiro é chamado de antigo multiculturalismo e trata das consequências do processo de conquista e de colonização, em que o "luminar em cada nação pós-colonial é a civilização ocidental tal como definida pelos conquistadores e construída pelos colonizadores originais e pelas levas dos que lhes sucederam"34. O multiculturalismo antigo é resultado da tentativa de disciplinar todas as nações a seguirem o padrão dos conquistadores e colonizadores, num esforço para eliminar as diferenças.

O segundo tipo de multiculturalismo é aquele em que os esforços do primeiro tipo são destruídos por uma fonte multirracial e por uma economia transnacional. Ele pretende "dar conta do influxo de migrantes pobres [...] e resgatar [...] grupos étnicos e sociais, economicamente desfavorecidos no processo assinalado" 34 . Este tipo visa, então, incluir a diferença ao invés de tentar apaga-la em uma busca pelo homogêneo. 0 que Silviano Santigo nos mostra é que o cosmopolitismo sempre existiu, desde a conquista e a colônia, e que seu resultado é o multiculturalismo. A questão é pensar, a partir daí, a maneira que esse resultado se projeta e é recebido pelos que o vivem: apagamento e homogeneização ou aceitação e inclusão da heterogeneidade. (SANTIAGO, 2004: 54-59) 
"identitis aguda", ou seja, uma patologia que culpa a nacionalidade portorriquenha por todos os problemas sofridos pelos que lá nasceram, independente da instância em que estes ocorrem. Lalo não sofre porque é portorriquenho, mas porque vive a condição de invisibilidade, comum a tantos outros sujeitos.

No texto "Neonacionalismo y fatiga de identidad en Puerto Rico", Juan Duchesne Winter aponta que a política anticolonial, também chamada de liberação nacional, seguida pelos favoráveis à independência de Porto Rico desde a década de 1960, entrou numa crise na década de 80 . Essa crise, ao invés de direcionar a questão para uma política anticolonial externa, resultou no abandono da questão colonial e sua substituição por uma política de identidade. A essa política, Duchesne nomeia neonacionalismo. O objetivo deste discurso, segundo o autor, é trazer à tona conflitos e diferenças já óbvios entre o âmbito portorriquenho e o estadunidense. Com isso, problemas gritantes dentro da ilha, como a contração dos serviços sociais e dos direitos democráticos, são esquecidos.

O surgimento das políticas de identidade, ou neonacionalismo, reside nos resultados dos plebiscitos realizados em Porto Rico, os quais mostram que grande parte da população é favorável à anexação da ilha aos Estados Unidos, como um estado federado. A possibilidade da anexação significaria o fim da consciência nacional portorriquenha, sob a qual o movimento nacionalista fundamentou seus argumentos ao longo de sua existência. Para evitar que a consciência nacional fosse suplantada, criou-se a ideia de que a identidade nacional é a base da consciência nacional. Sendo assim, a anexação com os Estados Unidos significaria a anulação da identidade nacional portorriquenha.

O problema, para Duchesne Winter, é que dentro do imaginário estadunidense, todas as políticas de identidade nacional transformam-se em questões relativas à identidade étnica. Portanto, ao forjar uma política de identidade nacional para Porto Rico visando barrar a anexação, o neonacionalismo encaixou a ilha perfeitamente nos moldes de funcionamento da maquinaria étnico-política que sustenta a hegemonia branca anglo-saxã existente. Dentro dessa maquinaria, a identidade hegemônica não é marcada pois é considerada normal. Por outro lado, as demais identidades transformam-se em algo espetacular. 
Dentro do jogo de identidades étnicas que coexistem nos Estados Unidos, Porto Rico possui três marcas que definem a sua. Nas palavras do autor:

"A ello corresponde que el país flote en el mar Caribe como ambiguo locus amoenus, oscilante entre la inclemente insularidad de su geografía y la blanda levedad que lo sostiene como un biodomo estadunidense en el trópico, insulado y aclimatado contra los peores rigores del clima socioeconómico del litoral”35

Ao que Duchesne nomeia "insularidad", lemos como uma marca islenha. Já o "biodomo estadunidense" é a marca atribuída em decorrência da fronteira e proximidade da ilha com os Estados Unidos. Por fim, o aspecto "aclimatado contra los peores rigores del clima" refere-se ao processo de latinização, na medida em que a cultura portorriquenha se aproxima das demais anglo-latinas.

Essas três marcas - islenha, fronteiriça e latina - forjadas pelo discurso identitário, foram as que converteram a identidade portorriquenha em mais um "capítulo discursivo de la etnopolítica estadunidense"36. A consequência final de todo esse processo é a conversão de um reclamo político anticolonial em uma representação de nação étnica, um espetáculo pronto para ser consumido pelo elemento hegemônico branco anglo-saxão.

A solução para essa questão é chamada de "cura negativa". O autor propõe acabar com as interpelações identitárias em todos os âmbitos, sejam eles acadêmicos, literários ou pessoais. Para primeiro, Winter recomenda eliminar a divisão das áreas de estudos por um organograma nacionalista como, por exemplo, "Estudos Portorriquenhos". Disso deriva a sugestão da adoção de uma perspectiva de estudos literários pós-nacionalista, sem apego às identidades nacionais. Por fim, ele pontua a necessidade de uma fuga radical da vitimização dos indivíduos baseada em argumentos identitários, como "sou portorriquenho e por isso sofro".

Para Lalo, a nacionalidade portorriquenha não é a causa de sua invisibilidade. Os símbolos e representações hegemônicas são os reais criadores dessa condição, que não é única aos que nasceram em tal ilha. Isso é desenvolvido no ensaio "A escrita riscada", do mesmo autor. Recuperaremos um fragmento em que Lalo explica

\footnotetext{
35 WINTER, Juan Duchesne. Neonacionalismo y fatiga de identidad en Puerto Rico. In: ARBOR Ciencia, Pensamiento y Cultura. Número 724, março-abril (2007), p. 268.

36 Ibidem, p. 269.
} 
como essa condição foi criada. Para ele, trata-se do apagamento histórico que se deu da periferia do Ocidente devido ao processo de "descobrimento":

"O "descobrimento" significa, entre outras coisas, nossa inclusão em um texto. Colombo o fez antes de todos e depois vieram os oficiais do reino, os cronistas e os clérigos. Ao desembarcar em cada ilha, um notário lia um fólio que dava um nome ao território e informava aos que não podiam entender, que a seguir, passariam a ser súditos do rei da Espanha. Milhares de anos de história eram riscados a golpe de pena. A escrita, tecnologia nova na América, nos colocava a força na história de outro. No que seguia, éramos parte mediante um ato que nos sentenciava à exclusão. A história de outro nos fundava ao nos escrever com as palavras mais falsas. [...] Fomos de outro porque nos escreveram e, ao fazê-lo, se apoiavam nas bases, se não do genocídio, ao menos do etnocídio. A história da escrita no Caribe e na América (essa outra palavra que nos apagava) nasce para trazer o silêncio e a morte. A escrita que nos nomeia é um ato de eliminação"37

Após uma reflexão sobre o apagamento da história dos países colonizados ao serem "escritos" por seus colonizadores, ao serem inseridos na "história" do mundo por eles, o ensaísta se detém especificamente no caso de Porto Rico. A segunda parte do ensaio é dedicada a isso e cruza a invisibilidade portorriquenha frente ao mundo com os próprios desafios dos portorriquenhos para gerarem seus discursos. $\mathrm{O}$ autor escreve

"Essa forma de inexistência que é a geografia.

Tirania insularista (e ocidentalista): pensar somente se referindo ao panorama do país. E, contudo, este país não existe fora deste país. [...]

Manifestação pessoal da tirania: não ter outra opção que ser parte do panorama. Não existo porque o país não existe. E, não obstante, escrevo. Será que o país terá que ser inteligível (régio para o Ocidente, localizável, assimilável, passado pela leitura do outro) para ser lido como alguém? Ou terá que suportar sempre esta ausência de imagem viva que os outros têm de nós?

Um porto-riquenho pode ser lido como alguém ou só como porto-riquenho? [...]

Não somos porto-riquenhos, mas sim $p$ r or iqu nh s. Para muitos, nossa única possibilidade de validação se dá pela adoção. Em qualquer momento estaríamos dispostos a mudar de pai. [...]

Ouvi dizer tantas vezes que Fulano (escritor, pintor, etc.) é o X porto-riquenho. Em outras palavras, é ninguém, é nada. Terrível forma de admiração. Rasura"38

\footnotetext{
${ }^{37}$ LALO, Eduardo. A escrita riscada. São Paulo: Selo Editorial Malha Fina Cartonera, 2016, pp. 16 - 17.

38 Ibidem, pp. $23-26$.
} 
Primeiramente, quando Lalo alega "não ter outra opção", reafirma-se a imposição da invisibilidade - aí descrita como inexistência - aos que possuem suas representações geradas apenas pelos agentes do discurso hegemônico, traduzido pela geografia. Não obstante, o autor escreve. A discussão sobre como uma condição é transformada em força motriz da escritura está por detrás de tal frase. Rememoramos um dos relatos de Los países invisibles, comentado anteriormente, em que tudo fluía bem na conversa com um escritor em um lançamento de um livro, até Lalo declarar ser portorriquenho e converter-se em invisível. Essa conversão é retomada no último parágrafo da citação.

A aproximação das ideias do ensaísta com as propostas de Duchesne Winter está explícita em "Um porto-riquenho pode ser lido como alguém ou só como portoriquenho?". Aqui, recuperamos o sujeito pós-moderno de Stuart Hall, sempre em mudança e transformado continuamente pelas representações ao seu redor. Lalo deseja ser um sujeito visível, alguém, e não apenas um portorriquenho, tendo em vista que sua constituição se dá pela intersecção de distintos aspectos. Eduardo Lalo não é só portorriquenho, é também um escritor, um sujeito. A invisibilidade lhe priva de configurar-se enquanto tal. Entretanto, sua escrita o faz.

\subsection{Uma escrita de inversões}

Após demonstrarmos que o insularismo cosmopolita, resultado da invisibilidade sofrida por Eduardo Lalo, possibilita que ele configure-se como sujeito e escreva, resta analisar a maneira que isto realiza-se ao longo de Los Países Invisibles. Até agora, tratamos sobre o efeito arquipélago do ensaio, o sensorium, ou seja, como o ensaísta vive diante e sobre os efeitos do mar predominantemente na primeira parte do ensaio.

Anteriormente, mencionamos que esta parte do ensaio é elaborada a modos de um diário de viagem: com cabeçalhos contendo cidade, dia, mês e ano. Somado a isso, há também a descrição de episódios que ocorreram com o autor durante a viagem. Aqui, cabe enfatizar que o gênero do texto não é diário, mas ensaio - tema que será tratado no capítulo três - e que, justamente por isso, abre espaço para a aproximação aos outros gêneros. No caso de Lalo, essas narrações são disparadoras de reflexões, uma das características do ensaio enquanto gênero textual.

Enfatizemos a seleção pelo modelo de um diário. Um escritor latino-americano, especificamente portorriquenho, território até hoje com o status de Estado Livre 
Associado - remontando às matrizes coloniais - viaja pela Europa e escreve um diário com suas impressões, as quais estabelecem uma relação direta com a ilha da qual provém. Estamos diante, portanto, da escritura de uma crônica histórica, porém invertida. Pensemos nos diários de Cristóvão Colombo sobre sua viagem à América. Estes escritos contêm relatos testemunhais que serviram para justificar à Coroa espanhola, de modo detalhado, as viagens e explorações que o almirante realizou no Novo Mundo. Estes textos nos mostram também as impressões de Colombo ao entrar em contato com o Outro, quando iniciou suas viagens para descobrir novas rotas comerciais.

A escrita de Eduardo Lalo consegue inverter essa perspectiva. Não é mais o europeu que viaja à América, mas o americano que descobre a Europa e nela vê - $\mathrm{e}$ consequentemente nos descreve - os aspectos e episódios que the interessam, para desenvolvimento de sua teoria da invisibilidade. O contato com o Outro se encontra em ambos os textos e o contraponto é claro. No ensaio $A$ escrita riscada, a performance da escrita é trabalhada com afinco e nos auxilia na compreensão desta escrita ativa realizada por Lalo:

"A primeira palavra escrita seria canoa, o veículo de viagem. [...] O insularismo da história colonial que chega até nossos dias, nasce com um conceito viajante, com o instrumento que transportava a cultura. [...] No Caribe, chega-se à escrita - Colombo anota em seu Diário a primeira palavra taina que se escreve mediante um ato, a seleção de um conceito, que a conquista e a colonização se ocupariam de rasurar. A primeira palavra escrita, aquela que Colombo escreveu com tinta em seu caderno de navegação, não foi "canoa", e sim canoz. Desde então, a escrita do Caribe não fez mais que repetir as consequências dessa união da morte e nascimento, do descobrimento de um mundo e sua condenação ao silêncio [...]. Nascemos para sermos riscados. Nossos textos, este mesmo que escrevo agora, se insere em uma tradição que desde o primeiro dia, os nega [...]. O "descobrimento" significa, entre outras coisas, nossa inclusão em um texto [...]. A escrita, tecnologia nova na América, nos colocava à força na história de outro [...]. Fomos de outro porque nos escreveram e, ao fazê-lo, se apoiavam nas bases, se não do genocídio, ao menos do etnocídio [...]. A escrita que nos nomeia é um ato de eliminação"39

O fragmento nos mostra a função da escrita quando os espanhóis chegaram ao Caribe, utilizando-a para registrar um descobrimento. Em outras palavras, visavam indicar o pertencimento do território à Coroa espanhola, apagando tudo que existia lá previamente. Ao escrever seus diários, Colombo insere a região do Caribe dentro de 
um texto pronto, da história ocidental. Além do apagamento das civilizações que existiam, essa escrita também implica em uma rasura, pois indica que algo existia e que este foi aniquilado em decorrência da imposição de um outro modelo.

Qual seria, portanto, o papel dos próprios caribenhos frente ao apagamento e à rasura que sofreram? A partir do excerto, ocupariam uma função passiva, de não reagir, de serem os que são inseridos por outro. Os discursos e representações do que é aceito como conhecimento, modo de vida, história, são importados pelo europeu que anula os desenvolvidos pelos caribenhos. Entretanto, ao utilizar os moldes de um diário e inverter a situação, ou seja, um portorriquenho que viaja à Europa e gera seu diário, Eduardo Lalo abandona essa posição de passividade para tornar-se um sujeito ativo, produtor de discursos. Assim, logra retirar o status de aniquilação que carrega a escrita do diário e utilizá-lo como inserção.

Nesse mesmo sentido, na terceira de Los Países Invisibles, uma leitura que o autor apresenta de Robinson Crusoé trata sobre o mesmo aspecto:

"Robinson Crusoe es también un texto sobre el colonialismo y la isla del náufrago es de hecho, de manera literal, un país invisible. En este sentido, es uno de los textos que primero aborda con cierto grado de complejidad la existencia y la condición ex - céntrica de gran parte del planeta. El náufrago de Defoe no tuvo más remedio que habitar el país invisible que constituye su isla sin descubrir. Es, por tanto, un "lector" de la invisibilidad, a la vez que descubridor, explorador, colono, cronista y perenne escrutador del horizonte, pues conserva siempre la esperanza de la escapatoria. El "salvaje" Viernes es un hombre sin nombre, alguien que solamente pudo ser la huella de su pie en la arena (en otras palabras, es el autor de un signo, acaso de una escritura, efímera) para que el representante de Occidente la lea con horror y lo sojuzgue. Viernes es así una suerte de primer escritor de la invisibilidad, el primero que hace un "texto" que se enfrenta a la tradición establecida por otro y por ello mismo fue el primer silenciado, el primero que otro borra en el momento mismo en que lo escribe"40

Robinson Crusoé também é um diário de um náufrago, um navegante inglês que sobrevive a um acidente e acaba em uma ilha deserta que, descobrimos depois, está no Caribe. O navegante realiza diversas viagens à contrapelo das recomendações de seus familiares de permanecer na Inglaterra e assumir os negócios de seu pai, até que em uma delas o navio naufraga e ele consegue salvarse ao chegar nesta ilha. Inicialmente, o diário contém as datas, em uma tentativa de

\footnotetext{
${ }^{40}$ LALO, Eduardo. Los países invisibles. Madrid: Fórcola Ediciones, 2016, pp. 97 - 98.
} 
manter uma marcação do tempo. Porém, depois de anos na ilha, o diário perde essas marcações e contém apenas menções como "após quase vinte anos habitando minha ilha". O processo de Robinson Crusoé nos interessa porque consiste na saga de um europeu que perde tudo no naufrágio e se vê obrigado a reconstruir sua existência em uma ilha que não possui nenhum recurso com os quais ele estava acostumado a viver. Com o decorrer do tempo, ele consegue construir uma moradia com cercado, muros, uma tentativa de cama e alguns artefatos de cerâmica à semelhança de louças como pratos, copos etc. Também consegue desenvolver uma plantação e criar gado, além de utilizar armas e pólvora que conseguiu recuperar de seu barco. Assim, nota-se que Robinson não se abre para uma nova maneira de viver utilizando o que está à sua disposição na ilha, mas adaptar estes materiais à sua anterior vida europeia, tratando de reproduzi-la o máximo possível. Tiago Pinheiro Guilherme, em sua leitura de Robinson Crusoé apresentada na tese "A literatura sob rasura: autonomia, neutralização e democracia em J.M Coetzee e Roberto Bolaño", pontua que a estratégia do náufrago supõe um grau zero de civilização, tomando a ilha como em um nível de anterioridade de desenvolvimento em relação ao padrão europeu por ele conhecido. Ao mesmo tempo, nada Ihe falta nessa ilha, é possível encontrar ou desenvolver comida e ferramentas, por exemplo, além do tempo e da tranquilidade necessários para fazê-lo, como nos relatos de meses gastos na confecção de uma tigela. Essas são as condições para que Crusoé cultive aquele espaço, numa tentativa de reprodução da vida europeia. Há uma original cópia, ou seja, pela primeira vez original - uma pessoa realiza essa reprodução dos padrões europeus numa ilha deserta - cópia. O resultado desse processo é, posteriormente, a escritura do livro, que consiste numa segunda reprodução, mas dessa vez no sentido inverso: é a ilha que se projeta em sua cultura, através da cultura das letras. A finalização do ciclo se dá com o regresso de Robinson à Bretanha e a escrita. Tiago Pinheiro escreve

"A ilha deserta já não é o lugar onde se habita, a metáfora da solidão soberana, mas o veículo, metáfora, para a ocupação imperial. Tais ilhas também viajam - cada navio colonizador carrega uma consigo para ser descoberta [...]. E é desse modo que a narrativa começa a circular, tornando-se mito da fundação e da reprodutibilidade. Um mito da cultura de ilhas desertas, que se multiplica e se cultiva enquanto tal" ${ }^{\prime 1}$

\footnotetext{
41 PINHEIRO, Tiago G. A literatura sob rasura: autonomia, neutralização e democracia em J.M. Coetzee e Roberto Bolaño. Tese (Doutorado)- Faculdade de Filosofia, Letras e Ciências Humanas, Universidade de São Paulo. São Paulo, pp. 45-46, 2014.
} 
A experiência de Crusoé transforma a experiência da ilha deserta em metáfora da ocupação imperial. O que ele viveu, a original cópia, transforma-se apenas em cópia, em modelo a ser aplicado em outras ilhas. Recuperamos, então, as palavras de Eduardo Lalo. Se a ilha deserta é o território que receberá o modelo de ocupação desenvolvido por Crusoé, ela se trata de um país invisível, isto é, um território lido pelo Ocidente como "grau zero da civilização" e pronto para ser incluído na história ocidental através de representações de outrem, como realizado por Cristóvão Colombo. Conforme pontuado por Lalo, Crusoé é, além de leitor da invisibilidade, descobridor, explorador, colono, cronista e examinador do horizonte, dada sua esperança de escapatória. Ambos estão em territórios desertos ou considerados como desertos - Colombo chegara em terras habitadas e a imposição do modelo europeu se deu como Crusoé realizou em uma ilha deserta - e possuem o poder de pertencerem às nações que escrevem à história, não às que a padecem.

Existe, simultaneamente, outro personagem que deve ser destacado no livro de Defoe: Sexta-Feira. Após muitos anos vivendo em completa solidão na ilha, Crusoé o avista e começa o contato com ele. Primeiro, destacamos que a maneira como ele é descrito é similar à maneira que Colombo descreve os nativos das Américas e ambos o fazem do mesmo modo que apresentam uma paisagem geográfica, por exemplo. Em Robinson Crusoé, temos:

"Era um sujeito de ótima aparência, muito bem-feito de corpo, com braços e pernas retos e compridos, não muito corpulento; era alto e bem formado, e, pelo que calculo, contaria uns vinte e seis anos de idade. Tinha um semblante bondoso, não um aspecto arrogante e feroz, mas parecia ter algo de muito másculo no rosto, ao mesmo tempo que transmitia a doçura e a suavidade de um Europeu também na expressão, especialmente ao sorrir [...].Quando me avistou, veio correndo em minha direção, [...] e depois disso, ainda deu todos os sinais de sujeição, servidão e submissão que se pode imaginar, para me dizer que seria meu criado pelo resto da vida"42

A descrição da aparência dos indivíduos, também uma constante nos diários de Colombo, possui algo que chama a atenção: semelhanças com o europeu. Se a ilha está pronta para ser colonizada porque não possui nada que se pareça ao modelo europeu, Sexta-Feira o possui. É como se isso tranquilizasse Crusoé, como se ele se permitisse o contato com o selvagem porque possui reminiscências europeias. De todas as formas, a pré-disposição à servidão também é pontuada, justificando-a. O

\footnotetext{
42 DEFOE, Daniel. Robinson Crusoé. São Paulo: Penguin Classics Companhia das Letras, 2011, p. 284.
} 
seguinte passo é ensinar a língua inglesa ao selvagem, para que o contato entre ambos se estabeleça. Com isso, diálogos sucedem, e o mais importante deles é o qual alerta Robinson Crusoé para a possibilidade de abandonar a ilha:

"Fiz a Sexta-Feira mil perguntas sobre as terras, os habitantes, o mar, a costa e as nações que ficavam perto; ele me contou tudo que sabia com a maior franqueza que se pode imaginar; perguntei a ele os nomes das várias nações de pessoas do tipo dele; mas o único nome que obtive foi Caribs, a partir do que logo entendi que estes eram os Caraíbas, que nossos mapas situam na parte da América que vai da boca do Rio Orinoco até a Guiana, e mais adiante até Santa Marta. [...] Essa parte das conversas com Sexta-Feira começou a me agradar muito, e a partir desse momento passei a cultivar alguma esperança de que, em algum momento, pudesse encontrar uma oportunidade de escapar daquele lugar; e de que ese pobre selvagem pudesse me ajudar"43

Esta passagem situa geograficamente a ilha no Caribe e, é a partir dessa informação, que Crusoé recupera a esperança de sair da ilha. O excerto também demonstra que, apesar de ser considerado pelo náufrago inglês como um selvagem absolutamente aculturado, a quem ele ensina a língua, a religião e abomina alguns hábitos como o canibalismo, Sexta-Feira é aquele que possui o conhecimento para salvar Robinson Crusoé. O europeu, o Ocidente, depende dos saberes no invisível para estabelecer-se. Lalo descreve a imagem do apagamento da escrita de SextaFeira, com a pegada de seu pé na areia, imediatamente aniquilada. Não obstante, é este mesmo ser invisível, totalmente desprovido de saber - conforme a leitura europeia - que o ajuda, por exemplo, a construir as canoas para a chegada ao continente. A ambivalência está nesse fato. O discurso ocidental vence, pois o selvagem torna-se servo e não é um sujeito ativo na inserção de seus saberes na história. Porém, sem eles o próprio "amo" jamais poderia tê-la escrito.

Retomando a tese de Tiago Pinheiro, nota-se que este libro é a construção de um olhar para o que está fora da Europa, mas nada se diz sobre aquele que recebe o olhar. Confirma-se que tudo que está fora do discurso do Ocidente é tido como invisível e material de conversão ${ }^{44}$. A partir daí, como Eduardo Lalo manipula esses fatos em seu ensaio? Através de ambivalência e dualidades, marcas constantes em todo seu texto. Conforme discorremos anteriormente, a seleção do diário e as

\footnotetext{
43 Ibidem, pp. 295 - 296.

44 PINHEIRO, Tiago G. A literatura sob rasura: autonomia, neutralização e democracia em J.M. Coetzee e Roberto Bolaño. Tese (Doutorado)- Faculdade de Filosofia, Letras e Ciências Humanas, Universidade de São Paulo. São Paulo, p. 46, 2014.
} 
características de sua escrita configuram uma inversão do processo realizado pelos cronistas do período de conquista e de colônia, o que inclui não só Cristóvão Colombo como também Robinson Crusoé. Neste último, além de representar o cronista, também trata-se daquele que habita o território invisível, ex-cêntrico, abordando, de acordo com o próprio Lalo, a complexidade da existência em um lugar assim. Ambos o fazem - tanto o inglês quanto o portorriquenho. A diferença entre ambos é a esperança que Robinson tem de sair da ilha, ao passo que esta não se manifesta ao longo do ensaio de Lalo, o que se confirma na primeira parte do livro, durante a viagem, quando o autor alega ter o mérito de sobreviver em sua condição de invisibilidade. $O$ tom melancólico da terceira parte, na qual o espaço geográfico do ensaísta são as ruas da ilha Porto Rico - outro paralelo entre Lalo e Crusoé - não deve ser confundido com o desejo de abandonar tal território.

As semelhanças entre Lalo e Sexta-Feira também existem em relação ao trauma histórico, à invisibilidade e à questão da aniquilação em pró de uma imposição. Entretanto, enquanto os conhecimentos de Sexta-Feira são imprescindíveis para que Crusoé atinja seu objetivo, o que de certa maneira poderia ser interpretado como uma inserção dele na história como sujeito ativo e não apenas passivo, Lalo o faz por meio de sua escrita, utilizando as ferramentas ocidentais comumente relacionadas ao apagamento para operar a inserção sobre a qual discorremos anteriormente.

Assim, essa escrita de inversões e dualidades é o modo através do qual Eduardo Lalo opera seu insularismo cosmopolita como força motriz de sua escrita. Um portorriquenho, representante de uma ilha, cujos deslocamentos pelo mundo permitem que seja um sujeito ativo. 


\section{CAPÍTULO II - A TERRA, O SOLO, AS CIDADES}

"El que vive en una isla tiene la imagen real de su propia vida"
Maria Zambrano Isla de Puerto Rico: nostalgia y esperanza de un mundo mejor

Los Países Invisibles traz, em seu próprio título, uma referência à Las ciudades invisibles, do escritor italiano Italo Calvino. As semelhanças e aproximações entre as duas obras não param por aí e passam por diversos âmbitos, desde as temáticas tratadas até a estrutura e composição da escrita. Por fim, alcançam também a construção de argumentos semelhantes em ambas. Isto coloca um acento na importância que as representações da cidade possuem no livro de Eduardo Lalo. Neste capítulo, exploraremos essas imagens e representações. Para tal, iniciaremos com uma exposição das afinidades entre Calvino e Lalo, de modo a auxiliar na descrição da maneira como este mobiliza a temática da cidade ao longo de seu livro. Para isso, também estabeleceremos também um contraponto com $A$ cidade das letras, de Ángel Rama, e La ciudad vista, de Beatriz Sarlo. Nosso objetivo é delinear um panorama sobre a cidade e o urbano no mencionado ensaio do portorriquenho.

\subsection{Nômade islenho: Eduardo Lalo e o périplo}

A segunda parte do ensaio, "La carretera número 3", apresenta o regresso de Lalo a Porto Rico após sua estadia na Europa, narrando, por exemplo, as impressões do ensaísta ao observar sua ilha natal desde o avião. Também trata de um passeio em família que o autor realiza com sua esposa e filhos para banhar-se em um rio. Para chegar no destino, Lalo percorre a estrada número três, segunda maior do território, que conecta Río Piedras a Salinas. A mudança de território entre a primeira e a segunda parte do ensaio, da Europa para Porto Rico, também implica em uma mudança de foco, da qual trataremos a seguir.

No começo da segunda parte, Lalo cita um trecho de Memoria de Ulises. Relatos sobre la frontera en la Grecia antigua, escrito por Fraçois Hartog, que diz "Deseoso de un inventario, el periplo tiene horror al vacío (al blanco): avanza 
empíricamente de un punto a otro, construyendo un espacio que es un trayecto" 45 . 0 ensaio nos oferece dois périplos: o primeiro, descrito na parte 1, consiste em uma viagem pela Europa. O segundo, tratado na parte 3, é uma viagem por Porto Rico, especificamente por San Juan de Puerto Rico, capital da ilha, onde o autor vive. Entretanto, há um terceiro périplo a ser destacado.

Se, na primeira parte do ensaio, o foco é exclusivamente a escrita, com os relatos de viagem de Lalo por terras europeias escritos à semelhança de um diário, conforme exposto anteriormente, a terceira parte destaca a leitura. Ao defender que a invisibilidade tem a ver, principalmente, com a ausência de um consumo de relatos e teorias provenientes de um território, o autor segue desenvolvendo suas ideias sobre territórios invisíveis, mas, a partir da segunda e majoritariamente da terceira partes, utiliza suas leituras como ponto de partida. A terceira parte do ensaio, "El experimento" consiste na parada de aquisição de livros e na valorização e leitura dos que compõem sua biblioteca. Isso é feito por meio de um capítulo composto por muito mais citações e reflexões que derivam delas. Em "El viaje”, Lalo nos conta e narra situações de sua viagem à Europa, a partir das quais originavam-se os argumentos do ensaio. Por outro lado, em "La carreterra número 3" e em "El experimento", são as leituras de sua biblioteca que se transformam em detonantes de suas ponderações.

Conforme Walter Benjamin, no conhecido ensaio "Desempaco mi biblioteca", a posse de livros é a relação mais íntima que um colecionista pode ter com eles. Adquirir um livro, para este tipo de personagem, é mais do que apenas comprá-lo, pois envolve reconhecer e atribuir destaque à forma como o livro foi incluído na sua coleção, na sua biblioteca particular. A aquisição envolve também contar de onde o livro veio e que história reside por detrás desta inclusão em seu acervo ${ }^{46}$. $O$ périplo da terceira parte do ensaio perpassa esses caminhos: uma viagem pelas leituras da biblioteca de Lalo e sobre como elas se deram, de que maneira os livros citados chegaram às mãos do autor, onde e de que forma se deu a leitura. Tudo isso se transforma em pontos de estalo para o aprimoramento de uma discussão sobre a condição de ser portorriquenho e a invisibilidade como um todo.

\footnotetext{
${ }^{45}$ LALO, Eduardo. Los países invisibles. Madrid: Fórcola Ediciones, 2016, p. 69.

${ }^{46}$ BENJAMIN, Walter. Desempaco mi biblioteca. Un discurso sobre el coleccionismo. In: Cuadernos de la Lectio, no 7, enero-julio 2018, p. 23.
} 
A respeito do diálogo dos escritores com suas bibliotecas, Ana Cecília Olmos escreve que "[...] ao arrumar suas bibliotecas, os escritores organizam uma tradição literária que delimita um lugar específico para suas poéticas e na qual eles se reconhecem, mas também à qual sua escritura, em última instância, se subordina"47. Durante o périplo por suas leituras, Lalo realiza a operação descrita por Olmos, visto que evidencia distintos trechos e citações que embasam e fomentam seu argumento principal, força motriz de sua escritura. A relação entre leitura e escrita é intrínseca, já que tudo se mobiliza em função de alimentar o argumento principal. O périplo pela biblioteca de Lalo implica em uma operação de situar sua escrita entre distintos autores nos quais ele se reconhece a partir de aproximações ou até mesmo oposições, conforme demonstraremos a frente. Sendo assim, podemos afirmar que as leituras são, em última instância, geradoras de sua escrita. A estrutura se repete: o autor nos conta alguma situação que se dá na cidade de San Juan, em espaços públicos ou privados. Tal situação envolve uma leitura, cujo trecho que lhe interessa é citado em seu ensaio. A partir dele, Lalo aproxima ou afasta o conteúdo de sua ideia de invisibilidade. Então, uma nova situação de leitura ou, em outras palavras, descrição da performance de uma leitura, é escrita e assim por diante. Como dissemos anteriormente, o périplo por San Juan é concomitante ao périplo por sua biblioteca e por suas leituras. O próprio autor escreve:

"La metáfora borgiana del universo como biblioteca tiene en mí uma variante. La biblioteca no existe, la grande, la única. Hay, en cambio, bibliotecas domésticas y portátiles. Y ciertos hombres nómadas que recorren el desierto, que es el universo, en busca de las palabras escritas que son su vida. En los oasis, esas ciudades del desierto, importan poco los monumentos, los palacios, las palmeras de dátiles, los preciados y escasos huertos. Mas los oasis son la intensificación de la experiencia, porque allí se encuentran las minas de libros. Y yo, nómada isleño, acudo aquí a cargar la sal de la escritura, sin la cual mi vida sería imposible"48

A passagem coloca duas imagens em paralelo: a da biblioteca e a da cidade. Eduardo Lalo menciona que suas bibliotecas, além de várias, são portáteis, isto é, não são fixas, podem ser transportadas com facilidade. De fato, ele o faz na primeira parte do ensaio, carregando-as por sua viagem, mas também o faz nas outras duas partes, transportando-as por San Juan. Então, ele escreve no excerto que os oásis, cidades

\footnotetext{
47 OLMOS, Ana C. Escritas descentradas: o ensaio dos escritores na América Latina. Rio de Janeiro: Papéis Selvagens, 2019, p. 86.

${ }^{48}$ LALO, Eduardo. Los países invisibles. Madrid: Fórcola Ediciones, 2016, p. 43.
} 
em meio ao deserto, possuem minas de livros, que são o que realmente importa delas. San Juan, metonímia para Porto Rico, seria uma cidade em meio ao vazio das águas - da mesma forma que um oásis em meio ao deserto - em que o que importa são os livros. Ao traçar sua trajetória por San Juan, pouco importam dados geográficos, menções a atrativos turísticos ou construções emblemáticas, mas as leituras que o autor realiza nesse espaço, afinal é sobre isso que ele escreve. As minas, como fenômeno natural, podem gerar sal e, com isto, abrem-se infinitas possibilidades para seu uso. As minas de livros de Lalo, suas bibliotecas, geram leituras e o produto final é o que ele nomeia "sal da escrita", que viabiliza sua existência. Conectam-se diretamente, neste trecho, leitura e escritura.

Sobre o mecanismo que conecta leitura e escrita, Roland Barthes, no livro $O$ rumor da língua, realiza interessantes reflexões sobre o tema. No capítulo "Da leitura", o pós-estruturalista francês move o foco de sua análise crítica do autor para o leitor, ou seja, não lhe interessa refletir sobre as intenções de quem escreveu determinado texto, mas sobre as reações que a leitura dele pode ocasionar. Barthes desenvolve o que seria uma teoria da leitura. Ele afirma que a leitura conduz o desejo de escrever. A atividade, a produção e o trabalho são resultados das leituras, que são "verdadeiramente uma produção [...] literalmente, de trabalho: o produto (consumido) é devolvido em produção, em promessa, em desejo de produção, [...] cada leitura valendo pela escritura que ela gera, até o infinito"49. Além de ser produção, a leitura se validaria, portanto, pelo seu produto, o desejo da escrita.

O leitor, segundo Barthes, converte-se em sujeito de produção de sentidos. A leitura não é algo passivo, mas ativo e geradora de um produto. Por isso, a importância de que um autor portorriquenho, cuja nacionalidade carrega impotência e uma pressuposta incapacidade de gerar discursos sobre si mesmo, realize um périplo por suas leituras e desenvolva, a partir de sua biblioteca, reflexões sobre sua obra e, consequentemente, sua condição invisível frente ao Ocidente. Lalo abandona a função de leitor que apenas se submete ao que consome e se constrói como um produtor de discursos. O próximo passo implícito nesse ciclo cabe a nós, seus leitores, e consiste em que realizemos uma leitura da leitura-escritura de Lalo, para que

\footnotetext{
${ }^{49}$ BARTHES, Roland. O rumor da língua. São Paulo: Martins Fontes, 2004, pp. 39-40.
} 
continuemos escrevendo e produzindo sobre um tema tão negligenciado quanto a invisibilidade.

Barthes e sua teoria da leitura-escritura nos ajudam a compreender a codependência de ambos processos ao longo de uma produção textual, colocando principal ênfase na ação do leitor. Por outro lado, Jacques Rancière em Políticas da escrita se debruça em outro aspecto deste processo. De acordo com o teórico argelino:

"A escrita está liberta do ato da palavra que confere a um logos sua legitimidade, que o inscreve nos modos legítimos do falar e do ouvir, dos enunciadores e dos receptores autorizados. É por isso, também, que ela é falante demais: a letra morta vai rolar de um lado para o outro sem saber a quem se destina, a quem deve ou não falar. Qualquer um pode, então, apoderar-se dela, dar a ela uma voz que não é mais "a dela", construir com ela uma outra cena de fala, determinando uma outra divisão do sensível"50

Segundo esse trecho, as palavras, depois de enunciadas, não tem dono. Quando alguém escreve, não sabe exatamente a quem está destinada sua escrita e a palavra pode ser apoderada por um interlocutor que faz com ela a divisão do sensível que deseja. Esse "sensível" a que se refere o autor trata-se de uma "divisão dos espaços - reais e simbólicos - destinados a essa ou aquela ocupação, uma forma de visibilidade e de dizibilidade do que é próprio e do que é comum"51. O sensível abarca, portanto, tudo: os discursos e as representações que, em última instância, regem o mundo tal como o conhecemos. Nas palavras de Lalo, o sensível seria o visível.

O processo de leitura-escritura de Lalo coloca em prática o mencionado por Rancière em dois momentos. O primeiro, quando ele mobiliza e lê sua biblioteca em função de sua escritura. Um exemplo, cujas implicações exploraremos mais adiante, é a utilização da filosofia do cinismo em decorrência da elaboração de sua teoria da invisibilidade, apropriando-se das palavras de R. Bracht Branham, Peter Slöterdijk e Michel Onfray sobre o tema. A partir de citações desses autores, Lalo desenvolve um paralelo entre o cínico e o habitante de um território invisível. É muito pouco provável que esse uso tenha sido previsto por estes autores, mas, conforme Rancière, as palavras enunciadas não possuem dono e estão à serviço da mudança do sensível

\footnotetext{
${ }^{50}$ RANCIÈRE, Jacques. Políticas da escrita. São Paulo: Editora 34, 2017, pp. 8-9.

51 Ibidem, p. 8.
} 
que o leitor deseja implementar. Entra em cena, nesse momento, o sujeito leitor de Barthes, que se apropria das palavras lidas, atribui-lhes um sentido e, a partir daí, produz um discurso, o qual resultará em uma mudança do sensível, das representações dos habitantes de territórios invisíveis tal como os conhecemos até então. Por outro lado, a própria escrita de Lalo é um discurso que será apropriado pelo leitor, produzindo nele uma escritura a depender da maneira que ele a realize. O leitor pode ser de um país invisível e compartilhar com o autor a condição por ele descrita, como também pode não o ser. Quem enuncia, neste caso Eduardo Lalo, não tem o controle desse processo, mas nos fornece sua tentativa de reorganização do sensível através de uma leitura ativa. Dessa forma, um escritor posicionado fora do sensível consegue construir um lugar de enunciação através de seu texto.

\subsection{Os países e as cidades invisíveis}

Uma das apropriações e dos processos de leitura-escritura latente no ensaio é o do livro de Italo Calvino, Las ciudades invisibles. A aproximação entre ambos livros começa pelo título. Para o senso comum, algo invisível refere-se à incapacidade de reconhece-lo através da visão. Entretanto, isso não implica em sua inexistência. A impossibilidade de ver algo com os olhos faz com que outros órgãos devam ser acionados para delimitar sua existência.

No livro de Calvino, o leitor se depara com um diálogo-duelo entre o viajante Marco Polo, natural de Veneza, e o imperador Kublai Khan. Este quer montar um império ideal embasado nos relatos que escuta daquele. Marco Polo viajou por cinquenta e cinco cidades, todas imaginárias e, portanto, invisíveis aos olhos humanos. O que as torna visíveis é o relato que Polo realiza delas. O livro se estrutura a partir de descrições das cidades, as quais sempre possuem nomes femininos, rodeadas por molduras textuais. Cada capítulo começa com um diálogo entre ambos, que normalmente contém questionamentos do imperador ao viajante. Então, seguem as descrições. As cidades, ao longo do livro, dividem-se em blocos, como "Las ciudades y la memoria", "Las ciudades y los signos", entre outros. Ao terminar as descrições das cidades do respectivo capítulo, este encerra com outro diálogo entre ambos.

A comunicação entre os dois se dá através de uma maneira intrigante, pois não conheciam um a língua do outro. Ao final do capítulo II, o narrador escreve: 
“... Recién llegado y sin saber nada de las lenguas del Levante, Marco Polo no podía expresarse sino extrayendo objetos de sus maletas [...] y señalándolos [...]. No siempre las conexiones entre un elemento y otro del relato eran evidentes para el emperador; los objetos podían querer decir cosas diferentes [...]. Pero lo que hacía precioso para Kublai cada hecho o noticia referidos por su inarticulado informador era el espacio que quedaba en torno, un vacío no colmado de palabras. Las descripciones de ciudades visitadas por Marco Polo tenían esta virtud: que se podía dar vueltas con el pensamiento entre ellas, perderse, detenerse a tomar el fresco, o escapar corriendo. Con el paso del tiempo, en los relatos de Marco Polo las palabras fueron sustituyendo los objetos y los gestos [...]. El extranjero había aprendido a hablar la lengua del emperador, o el emperador a entender la lengua del extranjero. Pero se hubiera dicho que la comunicación entre ellos era menos feliz que antes; es cierto que las palabras servían mejor que los gestos [...]; sin embargo, cuando Polo empezaba a decir cómo sería la vida en aquellos lugares, [...] le faltaban las palabras, y poco a poco volvía a recurrir a gestos [...]. Hasta el placer de recurrir a ellos disminuía en ambos; en sus conversaciones permanecían la mayor parte del tiempo callados e inmóviles" 52

O trecho mostra a dificuldade e a solução encontrada por eles para dialogarem. Marco Polo não falava a língua do imperador, o que o levou a recorrer a símbolos, objetos e sons no exercício da comunicação. A polifonia se deu nessa instância linguística, já que, conforme evidenciado pelo trecho, um símbolo, objeto ou som poderia adquirir diferentes sentidos conforme o interlocutor o "lê" - retomemos aqui o excerto de Jacques Rancière: depois de enunciadas, as palavras adquirem sentido conforme a vontade daquele que se apodera delas. Com o passar do tempo, como é comum a qualquer contato linguístico, gerou-se uma linguagem nova entre ambos. $O$ destaque é para a insuficiência das palavras, que as vezes não davam conta da descrição completa de Polo, o que o levava a continuar recorrendo a outros âmbitos tipos de linguagem, como gestos e objetos. A imagem final é de um diálogo em que, tanto o viajante como o imperador, permanecem a maior parte do tempo calados e imóveis, pois este não se dá majoritariamente pelo exercício da fala, mas pela leitura e interpretação que Polo faz do que viu em suas viagens, através de gestos ou mesmo do silêncio, e Klan dos relatos de seu interlocutor.

Aqui é inevitável aproximarmos Lalo e Calvino. Primeiro, a questão da viagem como matéria. A primeira parte do ensaio deriva da viagem à Europa e a segunda, conforme tratamos, do périplo pelas leituras e por San Juan. Segundo, o diálogo. Se, no livro de Calvino, o diálogo-duelo entre o viajante e o imperador se dá frente à um

\footnotetext{
52 CALVINO, Italo. Las ciudades invisibles. Buenos Aires: Ed. Minotauro, 1984, pp. 43 -44.
} 
tabuleiro de xadrez com constantes provocações entre ambos, no texto de Lalo isso se dá entre o viajante - o próprio autor - e o leitor. Este assume o papel de quem ouve as descrições das duas viagens, enquanto aquele utiliza de todos os seus instrumentos linguísticos para comunicar-se: uma primeira parte que se assemelha a um diário de viagens e as demais carregadas de leituras, composta pela sua biblioteca. O duelo é entre um autor que quer provar que é sujeito e produtor de discursos - enfrentando sua invisibilidade - e um leitor que consiste, entre outros, de alguém proveniente de um Ocidente que sempre quis anular sujeitos como Eduardo Lalo.

Em Calvino, as descrições das cidades visitadas sempre se atêm ao modo de vida dos habitantes e à cosmovisão que eles possuem a respeito do universo ou à relação que estabelecem com algum aspecto da vida, conforme expressado pelos títulos das sessões: as cidades e a memória, o desejo, os signos, a sutilidade, os intercâmbios, os olhos, o nome, os mortos, o céu, a continuidade e o esconderijo. Há, no entanto, uma exceção na descrição das cidades que se parecem muito à cidade da qual Marco Polo sente falta, Veneza. Nestes casos, o leitor se depara com descrições topográficas de canais, barcos, pontes. Todavia, Marco Polo jamais menciona o nome próprio dela, Veneza, o que é questionado pelo imperador:

"[...] Sire, ya te he hablado de todas las ciudades que conozco.

- Queda una de la que no hablas jamás. [...]

- Venecia - dijo el Jan. [...]

- ¿Y de qué otra cosa crees que te hablaba? [...]

- Sin embargo, no te he oído nunca pronunciar su nombre.

Y Polo: cada vez que describo una ciudad digo algo de Venecia [...] Para distinguir las cualidades de las otras, he de partir de una primera ciudad que permanece implícita. Para mí es Venecia"53

Esse trecho mostra que o contraponto para todas as descrições de Polo, sejam elas a respeito do estilo de vida ou da topografia, é sua cidade natal. Veneza está implícita ao longo de todo o livro, que cruza duas temáticas: memória e cidade. 0 imperador, ao final desse diálogo, questiona Marco Polo, alegando que se ele pergunta ao viajante sobre Veneza é porque quer saber a respeito dela. Frente a isto,

\footnotetext{
53 Ibidem, pp. 62-63.
} 
o viajante alega que "Las imágenes de la memoria, una vez fijadas por las palabras, se borran [...]. Quizás tengo miedo de perder a Venecia de una vez por todas, si hablo de ella. O quizás, hablando de otras ciudades, la he ido perdiendo poco a poco"54. Há, nesse diálogo, uma ambivalência: falar de Veneza implica em sua perda, pois a memória é traiçoeira se fixada à linguagem. Por outro lado, Veneza já foi perdida, misturando-se e penetrando em todas as descrições realizadas.

Novamente, somos convocados a aproximar o autor italiano e o portorriquenho. Primeiro, vale pontuar que Lalo escreve seu diário de viagens na primeira parte do ensaio desde quatro cidades, sendo a segunda delas Veneza. Somado a isso, conforme já expusemos anteriormente, tanto Marco Polo quanto Eduardo Lalo estabelecem suas cidades de origem como contraponto de suas escritas. Enquanto Polo afirma categoricamente "cada vez que describo una ciudad digo algo de Venecia", Lalo o faz na primeira parte através das reminiscências portorriquenhas e, na segunda e terceira partes, com o trajeto de leituras que delineia, ao final, San Juan. Nas palavras de Lalo "Sólo esta ciudad, por ser mía, me permite imaginar cualquier otra"55. Por fim, interessa-nos também mobilizar o conceito de hipervisibilidade, elaborado pelo ensaísta e também explorado previamente, para associa-lo à uma interessante fala de Marco Polo neste diálogo. O viajante veneziano alega não referirse diretamente à sua cidade natal por dois motivos. Inicialmente, porque tem medo de perder suas recordações dela se falar sobre a mesma constantemente e, depois, porque já perdeu as reminiscências dela justamente por ter falado tanto de outras cidades. O conceito de hipervisibilidade trata desse aspecto: uma cidade como Veneza, que segundo Lalo possui tantos discursos a seu respeito, se converteu na cópia desses discursos, numa reprodução do que é dito sobre ela, perdendo, desta forma, sua visibilidade. A cidade é invisível, o que vemos é a cópia de suas representações. O mesmo ocorreu com Marco Polo, que por projeta-la tanto de forma implícita em suas descrições, perdeu-a de vista. Ela se tornou, então, invisível, diluída nos textos do viajante sobre outras cidades. Em Lalo, a cidade se dilui nos discursos feitos sobre si mesma e, em Polo, nas descrições de outras cidades. Para os dois o excesso de discursos é gerador de invisibilidade. Em Calvino, também, a invisibilidade ultrapassa Veneza e atinge outras cidades. Um exemplo disso está em "Las ciudades

54

55 LALO, Eduardo. Los países invisibles. Madrid: Fórcola Ediciones, 2016, p. 94. 
y la memoria 3", em que Marco Polo descreve Zora. O viajante diz: "Pero inútilmente emprendí viaje para visitar la ciudad: obligada a permanecer inmóvil e igual a sí misma para ser recordada mejor, Zora languideció, se deshizo y desapareció. La tierra la ha olvidado" 56 . O que ocorreu em Zora, segundo tal descrição, é o mesmo que ocorreu na Veneza que Lalo observou: a cidade foi engolida pelo excesso de discursos a seu respeito. Na descrição de Marco Polo, a cidade teve que permanecer igual a si mesma, ou seja, aos discursos e representações existentes sobre si mesma, para poder ser recordada. Este processo, em última instância, implicou no seu desaparecimento, igual à Veneza visitada por Lalo.

Tanto Eduardo Lalo quando Marco Polo não descrevem efetivamente seus lugares de origem. Embora San Juan seja o espaço onde se dão as leituras-escrituras das partes dois e três do ensaio e o constante contraponto da primeira parte, não há uma descrição topográfica da ilha, com o número de habitantes, seu relevo, sua geografia, clima etc. O que Lalo realiza, de modo semelhante ao viajante veneziano, é tratar do que é um "estar no mundo portorriquenho", a partir de sua teoria da invisibilidade.

\subsection{0 assalto à cidade letrada}

Ao nos debruçarmos sobre como Lalo relaciona suas leituras-escrituras com a invisibilidade portorriquenha, podemos afirmar que ele se encontra na esteira do sujeito que se desloca entre uma perspectiva interna e externa da cidade das letras, como participante dela e mero observador de seu funcionamento. Isso pode ser verificado predominantemente na terceira parte do livro Los países invisibles, nomeada "El experimento". O experimento do qual trata o autor é parar de comprar livros e ler o que está acumulado em sua biblioteca pessoal. Ao longo desse período, percorre as ruas de San Juan de Puerto Rico circulando com seus livros por espaços como cafeterias, livrarias e centros comerciais. O disparador das reflexões que realiza é, ao chegar em algum desses lugares, compartilhar com o leitor seu ato de leitura e, através dele, citações e reflexões sobre temas que perpassam todo o livro: a invisibilidade de Porto Rico frente ao Ocidente e o que significa ser um escritor portorriquenho. As reflexões se dão majoritariamente em espaços públicos, embora algumas ocorram dentro de sua casa. Pelos dois âmbitos, delineia um caminho de

\footnotetext{
${ }^{56}$ CALVINO, Italo. Las ciudades invisibles. Buenos Aires: Ed. Minotauro, 1984, p. 34.
} 
recordações por meio de leituras - realizadas, ainda não realizadas, a serem realizadas, apenas iniciadas, e finalizadas, mas que merecem uma segunda leitura. É como se Lalo nos segurasse pela mão e nos levasse para caminhar com ele pelas ruas de uma San Juan que reconhece por via pública e via leitura.

Em dado momento, refletindo sobre o ato da leitura, o autor se pergunta - e nos pergunta ao mesmo tempo: “¿La lectura es una forma de reconocer al mundo y el tiempo, pero no sería más efectiva cuando lo hace desde la conciencia de su precariedad?"57. O verbo reconhecer chama a atenção por sua polissemia. Segundo o Dicionario de la Lengua Española da Real Academia Española, mobilizamos alguns significados de "reconocer" que dialogam com a citação anterior. O verbo pode referirse ao ato de reconhecer com a finalidade de conhecer, estabelecer uma identidade e explorar de perto para obter determinada informação. Por outro lado, há definições que aludem à admissão ou aceitação da legitimidade ou de uma qualidade e condição de algo. Consideramos, então, que a viagem pela leitura realizada pelo portorriquenho é, em suas próprias palavras, uma forma de explorar de perto San Juan, visando conhecer e estabelecer uma identidade para tal cidade. Mais do que isso, se retomamos o argumento principal do livro, que Porto Rico é um país invisível devido à falta de olhares e de discursos produzidos sobre ele e por aqueles que o habitam, convertendo-o em um não território, geopoliticamente inexistente por ser parte dos Estados Unidos ("este país não existe fora deste país"), ao reconhecer esse mundo e esse tempo - San Juan da contemporaneidade - também implica em aceitar a legitimidade de tal território. Lalo o faz por meio da escrita de seu ensaio que, além de conter trechos em que conta a própria performance da escrita, também promove a leitura.

Entretanto, a segunda parte da citação menciona o lugar a partir do qual realiza esse reconhecimento pela leitura, um lugar de consciência de sua precariedade. Estar nesse lugar, em decorrência de sua nacionalidade inexistente, invisível, o posiciona como exterior à cidade letrada. Delineia-se uma dualidade: sua exterioridade em relação à cidade letrada é a motivação para manejar os artifícios dela e construir um mapa de San Juan. Em uma de suas reflexões sobre as livrarias da cidade, Lalo escreve:

\footnotetext{
${ }^{57}$ LALO, Eduardo. Los países invisibles. Madrid: Fórcola Ediciones, 2016, p. 83.
} 
"Llevo acaso media vida tratando de conocer a este lugar que ha sido, más que un país, una condición. Comprendo que una de mis formas de hacerlo ha sido a través de los volúmenes de sus librerías. Recuerdo, por poner un ejemplo arbitrario, cómo una copia de carpeta dura de El benefactor de Susan Sontag, en edición mexicana, pudo estar más de una década en una librería del segundo piso de Plaza de las Américas, sin que nadie la comprara, y cómo este hecho expresaba, mediante la materialidad del libro, con independencia de su lectura, una de las imágenes posibles de estas calles, una descripción de lo que significaba vivir aquí. Los libros me protegían de esto, de la ciudad desnuda, de la ciudad sin más, sin esperanza, sin lectores."

Neste excerto, o autor expõe que não só a leitura, mas a própria materialidade dos livros, a presença - ou a não ausência, o que constata em si uma outra ausência, a de um público leitor - dele em uma livraria gera uma imagem da cidade, do que significa viver em San Juan. A terceira parte do ensaio desenha e nos mostra tais imagens, resultados de leituras e da materialidade livresca em si.

Ao longo de "El experimento", ponderações sobre a escrita são constantes. O sujeito que escreve oscila entre duas posições, a de questionar a validade e a importância de sua escritura e a de reafirmar ambas. Nas palavras do autor:

"Imagino, o más bien alucino, el portento de poder escribir un día como punto final de algún texto: "Aquí deja de escribir para siempre Eduardo Lalo". Poder trazar, con plena conciencia, la última letra y, al hacerlo, lograr estar más allá de la vanidad y la gran lista de razones por las que no se debe escribir, y por las que, al menos parcialmente, se escribe. ¿Puede uno - puedo yo - renunciar a la escritura como he renunciado a comprar libros? ¿Podría llegar al extremo de esta negación? Cada día me convenzo más de que esto es posible y que, incluso, no tiene por qué ser tan doloroso. La escritura puede llegar a no importar aún si se le ha dedicado la vida. Ése habría sido el camino para llegar a este comienzo de libertad. No podría prescindir de su práctica apasionada, pero a la vez sé que no hay por qué ser escritor toda la vida. [...] Me tomó años tragar y digerir el dolor de no poder formar parte de una sociedad con capacidad de fraguar su destino, en la que mi trabajo y el de tantos otros pudiera contribuir a una mayor potenciación, a crear un espacio para nosotros en el mundo"58

O autor alega estar cada dia mais convencido da possibilidade de abandonar a escrita, de escrever a frase que seria o ponto final de sua obra, negar e renunciar a escrita. Abandonar a escrita seria, portanto, abandonar a luta e vislumbrar a liberdade. Não obstante, pouco depois, Lalo reconhece que seu trabalho é criador de um espaço para sua sociedade, portorriquenha, que não consegue escrever seu destino e, por isso, sua escrita pode contribuir com ela. Novamente, neste texto de dualidades, 0

58 Ibidem, pp. 87-88. 
escritor se divide entre abandonar o trabalho e ser livre ou entrar de vez na batalha pelo poder que Ihe atribui a cidade letrada em relação a possibilidade de sair - junto com a sociedade em que vive - de seu lugar marginado no Ocidente. Não se deseja modificar a estrutura, mas reforma-la e inserindo Porto Rico nela.

Angel Rama em $A$ cidade das letras, explica que a cidade letrada tem feito, em um processo que segue até a atualidade, uma adaptação às mudanças, tentando, ao máximo, manter seu status quo e sua autonomia. Um artifício foi, por exemplo, sacralizar a leitura e a escritura, em um momento em que seu acesso na América Latina era muito reduzido. Ao longo de uma descrição da "gesta del letrado", do funcionamento de um "dispositivo disciplinario y ordenador, las jerarquías y la racionalización, la cooptación del sector por el poder y el estado" ${ }^{59}$, Rama demonstra que "toda tentativa de rebater, desafiar ou vencer a imposição da escritura passa obrigatoriamente por ela. [...] a escritura termina absorvendo toda a liberdade humana, porque só no seu campo de batalha se desenrola a batalha de novos setores que disputam posições de poder"60. Em nenhum momento a busca foi pela destruição da cidade letrada, mas pelo seu acesso por diferentes grupos, de modo cada vez mais democrático, culminando na formação dos partidos políticos da atualidade, que apesar de possuírem demandas populares e universais, não implicam em uma alteração da estrutura de poder. Segundo Rama, "devia ressaltar-se o que não se modificou na tradição política, nem sequer nessa primeira abertura democrática da América Latina: [...] não se enxerga nenhuma outra via capaz de gerar uma mudança na sociedade que não seja a ocupação do poder central" 61 ou, em outras palavras do mesmo crítico, "mais do que romper com o passado, aspiram à sua reforma"62.

Rama parece dialogar diretamente com o conflito de Eduardo Lalo: abandonar a escrita para alcançar a liberdade ou seguir escrevendo na tentativa de modificar a estrutura da cidade das letras em si. O autor alcança um veredito e decide permanecer no campo de batalha. Entretanto, o realiza como um letrado das margens, cujo objetivo não é manter um status quo de cidade letrada, mas tentar garantir, na medida do possível, a existência do território de Porto Rico. Lalo escreve:

\footnotetext{
59 COLOMBI, Beatriz. La gesta del letrado (sobre Ángel Rama y La ciudad letrada). In: Orbis Tertius, 2006 11(12). ISSN 1851-7811, p. 4.

${ }^{60}$ RAMA, Ángel. A cidade das letras. São Paulo: Boitempo, 2015, p. 57.

61 Ibidem, p. 118.

$62 \_$p. 109.
} 
"La posición del artista o del filósofo en los países invisibles no es la misma que en Occidente: aquél que es geográfico, político y simultáneamente una forma del espíritu. Los países invisibles son un anuncio del futuro cada vez más inminente del Occidente geopolítico y, en nuestra labor, que puede parecer insignificante o patética ante los ojos de tantos, están las lecciones estratégicas para aquellos que, por el momento, mantienen en sus sociedades la ilusión de la escucha, la influencia y la pertinencia"

À diferença do letrado do Ocidente, os letrados que provêm de países invisíveis utilizam estratégias para manter a ilusão da escuta, da influência e da pertinência deles. O que se quer garantir, em última instância, é a existência desses países, sua visibilidade. A existência para os habitantes desses territórios configura-se pela possiblidade de que seus discursos possam ser lidos pelo Ocidente. Entretanto, à diferença da cidade letrada padrão, a possibilidade de leitura não implica sua obrigatoriedade, embora mantenha essa "ilusão".

Em um outro ensaio do mesmo autor, a inexistência de Porto Rico se materializa: "Também quando criança, abri um atlas. No seu centro estava a página dupla de um mapa-múndi. Na escola eu havia estudado as viagens de Colombo e tentei fazê-las com o dedo. [...] Porto Rico não existia. No seu lugar, estava o azul do mar. A aniquilação chegara inclusive na geografia". O trecho, retirado do ensaio "A escrita riscada", trata da inexistência da ilha no próprio atlas. Permanecer nesse campo de batalha de signos significaria, portanto, inserir a ilha no Ocidente, literalmente, fazê-la ser vista - e lida - no mapa. A maneira de fazê-lo é via escrita, através do reconhecimento de San Juan e de sua legitimidade enquanto território. $O$ delineamento de um mapa, neste caso composto por leituras e escritas, é uma tática para materializar sua existência, utilizando as armas fornecidas pela cidade letrada ${ }^{63}$. Promover um assalto à cidade letrada, como disse Ángel Rama, e combater com as armas que ela ensinou. Por não poder vence-la, juntar-se, inserir-se nela.

\subsection{San Juan vista}

A respeito de Eduardo Lalo e as cidades, vimos que ele realiza um périplo por sua biblioteca, ao longo do qual delineia-se a cidade de San Juan por meio do

\footnotetext{
63 É interessante resgatar a imagem do mapa, do desenho gráfico, mobilizada por Rama, pois nele existe a união entre signo e significado, por tratar-se de uma representação (desenho) da cidade (coisa representada/realidade). No mapa, a representação, o desenho, o signo, adquire total independência da realidade, da cidade real, de seu significado, além de garantir, em certa medida, a manutenção do futuro dessa realidade, numa tentativa de que ela seguisse a ordem imposta pela sua representação. Os signos, a ordem, deveriam manter-se intactos, inalteráveis. (RAMA, 2015: 23)
} 
dispositivo da leitura que gera escritura. Dentro desse périplo, tratamos das cidades invisíveis de Marco Polo e da cidade letrada de Ángel Rama. O contraponto do ensaio de Lalo é San Juan e ele o faz apoderando-se da cultura letrada. As descrições de San Juan não são geográficas, mas sobre o existir no mundo como um portorriquenho. Isto se dá com descrições de cenas de San Juan, muitas delas em livrarias, cafés e bibliotecas, que se assemelham às fotografias.

Este método de descrição se aproxima do que Beatriz Sarlo realiza em seu livro La ciudad vista, escrito após quatro anos de caminhadas pela cidade de Buenos Aires com o objetivo de vê-la e escutá-la, registrando as imagens com uma câmera digital ou em um caderno. Na introdução, a autora menciona a ideia de "barroquismo de superficie" de Christine Buci-Glucksmann, que consiste na captura de uma imagem que seria o resultado de um olhar conjunto e, simultaneamente, alcançaria uma "una escritura del detalle, donde el ver y el saber se dan al mismo tiempo"64. Essa é a metodologia utilizada pela autora, imagens que reproduzidas ou descritas e possibilitam a concomitância entre ver uma cena e construir um saber a respeito dela. Lalo, de sua parte, nos dá imagens de sua cidade que, como disse Christine BuciGlucksmann, são escritas dos detalhes que permitem que o leitor veja e saiba a seu respeito. Como essas imagens se articulam na construção da descrição de San Juan?

A resposta deste questionamento se dá através de um contraponto literário. No livro Isla de Puerto Rico, escrito pela espanhola Maria Zambrano, temos a visão e a descrição de uma viajante sobre a ilha. Ela se posiciona como encantada pelo seu charme e descreve o território como uma possibilidade de que o europeu proveniente de um país fracassado, adjetivo que ela mesma utiliza para tratar da Espanha, se reconecte com o passado e com a esperança de melhorar o presente se a atenção se voltar à essência de seu país. O ponto que Zambrano defende ao longo de seu texto é que Porto Rico é um território ideal pois une os melhores mundos: as características positivas da América do Norte - referindo-se aos Estados Unidos - e da Espanha. Para isso, ela descreve cenas que vivenciou na ilha que enaltecem essas duas nações. Ela nos apresenta o que Beatriz Sarlo chama de versão da cidade ${ }^{65}$, uma San

\footnotetext{
${ }^{64}$ SARLO, Beatriz. La ciudad vista. Buenos Aires: Siglo Veintiuno Editores, 2009, p. 10.

65 Para Sarlo, uma cidade escrita constrói um modelo que conecta a realidade da cidade com a experiência nela vivida e o ideal de cidade de quem escreve. Estes três fatores fabricam uma cidade, ou melhor, uma versão dela.
} 
Juan escrita e fabricada por ela, baseada na experiência que ela viveu em sua viagem, o que ela considera como realidade da cidade e o ideal que a própria Zambrano possui de que o melhor para uma nação fracassada seria reconectar-se com seu passado.

Eduardo Lalo realiza o mesmo procedimento que Zambrano, conforme descrito por Sarlo, mas alcança resultados muito distintos. Ao cruzar a realidade de San Juan com a experiência que ele viveu lá e o ideal de cidade que ele tem, o resultado é um relato de tom melancólico que por vezes menciona o fracasso, a queda, a ruína, coisas que Sarlo menciona como traços da cidade real, não necessariamente da cidade escrita. Concluímos, portanto, que a cidade real se sobrepõe à escrita no ensaio de Lalo. O resultado disso é a construção de sua autoimagem em San Juan como um cínico.

Se o livro de Zambrano trata das impressões de uma viajante espanhola à Porto Rico, o ensaio de Lalo é escrito por um portorriquenho que também realizou muitas viagens, uma delas inclusive tratada na primeira parte do ensaio. Esse fator não pode ser deixado em segundo plano, pois o contato com o outro modifica os três aspectos que fabricam uma cidade escrita (realidade, experiência e ideal). A maneira como se deve ler um viajante que escreve sobre sua própria cidade é pontuado por Beatriz Sarlo:

"Se lee a los viajeros que escriben sobre la ciudad propia con una mezcla de
dos curiosidades. La primera, mezquina, impulsa a descubrir los "errores" [...].
La segunda es una curiosidad intelectual y estética. En última instancia se
busca una respuesta a la pregunta sobre lo que el otro vio y pasa desapercibido
para los locales porque es poco significativo [...]; porque ha sido pasado por
alto aunque, en el momento en que el extranjero lo registra, empiece a ser
reconocido; o, finalmente, porque no se lo creía un rasgo peculiar, que pudiera
identificar la ciudad propia. El argumento del extranjero señala una tipología o
un "estilo", desgajándolo de su experiencia local cotidiana y de su historia, para
centrarlo precisamente por medio de su descentramiento. Lo coloca en otra
parte, y lo transforma en algo central para la mirada descentrada del
extranjero" 66

A autora considera que o viajante que escreve sobre sua própria cidade é um estrangeiro, de forma que ele está apto a vê-la com o olhar do outro. Este novo olhar passa pelo apontamento dos erros nela existentes, como se a viagem implantasse um manual do que é uma cidade ideal na cabeça do escritor. Somado a isso, o viajante

66 Ibidem, p. 188. 
que fabrica sua cidade escrita em contato com o outro, possui a possibilidade de perceber coisas pouco significativas para os locais. Em outras palavras, o olhar estrangeiro modifica o que um habitante local vê como central, descentraliza o que alguém que não viajou à outras partes considera como fundamental na intersecção realidade, experiência e ideal.

O fato de Lalo ter vivido sua experiência de contato com o outro europeu e as consequências disto no texto - o insularismo cosmopolita sobre o qual tratamos também possibilita que os fatores considerados na fabricação da San Juan escrita sejam distintos, porque a San Juan que ele vê, sua San Juan vista, é outra. Lalo tem o olhar direcionado para os livros, para os leitores, para as (não) escrituras da cidade. Seu universo orbita nesse sentido e isso é um marcador de diferença em relação aos seus conterrâneos, conforme exposto em muitas partes do livro, entre as quais podemos exemplificar

"Hace más de veinte años, cuando regresé a Puerto Rico después de estadías en Estados Unidos y Europa, imaginé que llegaba a un país en el que se podía construir una sociedad dura como las que acababa de dejar. Encontré en cambio esto, esta debilidad fluida. [...] Me tomó años tragar y digerir el dolor de no poder formar parte de una sociedad con capacidad de fraguar su destino, en la que mi trabajo y la de tantos otros pudiera contribuir a una mayor potenciación, a crear un espacio para nosotros en el mundo. Me tomó mucho tiempo aceptar esta carretera número 3 por lo que era, una más de nuestras escrituras catastróficas [...]"67

"Salí de la librería en busca de un banco, pero cuando pasé frente al local de la cadena El Mesón, decidí entrar [...]. Ocupo esta mesa desde hace más de media hora, con sólo una taza de cartón sobre la bandeja que me entregaron al ordenar. Escribo y es de imaginar que me vean como esos locos que llenan página tras página sin poder detenerse" 68

Esses dois trechos mostram exatamente o olhar do viajante a respeito de sua própria cidade e o olhar de seus conterrâneos com um marcador de diferença. $O$ primeiro mostra que a San Juan cidade escrita de Lalo é a das letras, ou melhor, dos discursos e representações. O próprio ensaísta marca suas viagens, como se avisasse ao leitor que isso lhe assegura um olhar distinto. Há, então, a reflexão sobre uma San Juan em relação ao trabalho do escritor, ao quanto este poderia ser potencializado, e à marginalização das escritas na ilha. Por escrita, entende-se

\footnotetext{
${ }^{67}$ LALO, Eduardo. Los países invisibles. Madrid: Fórcola Ediciones, 2016, p. 88.

68 Ibidem, pp. 96-97.
} 
discursos e representações, tudo que a própria cidade produz, como a estrada número 3, uma "escritura catastrófica". Esta é a cidade escrita de Lalo, cruzando a realidade, a experiência do escritor, e seu ideal, em que o trabalho dos escritores pudesse contribuir mais na produção de discursos. Por outro lado, o segundo excerto marca o olhar dos portorriquenhos para esse estrangeiro. O escritor escreve que deve ser visto como o estranho que senta em um café e escreve sem parar. Ele mesmo se sente estranho e assume que é visto dessa forma. Essa diferença resultante das viagens, tanto no olhar quanto no ser olhado, resulta na autoconstrução de Lalo como um cínico.

\subsection{Invisibilidade e cinismo}

Em linhas gerais, pois o objetivo deste trabalho não é discorrer sobre escolas filosóficas mas verificar como elas são mobilizadas no desenvolvimento da teoria da invisibilidade, o cinismo é a filosofia da ação em preterimento da teoria. Diógenes, seu fundador, teve uma vida exemplar nesse sentido: não há livros e registros sobre sua teoria cínica, o que sabemos é pelo que se conta, pelas palavras de outros. Não obstante, ele levou uma vida cínica, seguindo os três princípios básicos desta filosofia.

O primeiro fundamento é a valorização da autarquia, do governo de si mesmo. Isto implica na não dependência de bens externos, vistos como supérfluos. O próprio Diógenes vivia como o que atualmente se consideraria um mendigo, dentro de um barril, portanto apenas sua roupa de corpo e um cajado para auxiliar em sua locomoção. O segundo é a liberdade em relação às convenções sociais. Na prática, isto significou uma afronta às regras que controlavam a sociedade da época. Diógenes, por exemplo, fazia suas necessidades e se masturbava em praça pública. Ele afirmava que não encontrar nenhum homem de verdade porque todas as pessoas que via eram dependentes de convenções sociais e de bens. Por fim, o último fundamento é o da apatia, a não afetação com estímulos externos, não se deixar levar pela situação. Outro exemplo, Diógenes fora visto pedindo esmolas para uma estátua e, quando questionado do porquê, alegara que era uma maneira de se acostumar à uma vida de fracassos.

Não é difícil perceber que os cínicos são vistos com diferença pelos que estão ao seu redor. Eduardo Lalo se constrói como um cínico em seu ensaio. $O$ autor 
escreve que essa linha filosófica o permite perceber que a própria filosofia não é uma escapatória, mas um diálogo com as condições materiais de existência. Lalo escreve:

"Pensar hoy, desde los países invisibles, es pues, se quiera o no, se esté consciente o no, una postura cínica, sobre todo si se escribe teniendo como interlocutor teórico a un Occidente que no escuchará o no se esforzará por comprender que el mundo ni la tradición se limita a lo que se asume como una realidad dada y propia. Hacerlo, como pretendo, con conciencia plena del acto, cómodo por así decirlo, con mi tonel y mi medida de habas, es un acto que convierte lo invisible en un nuevo continente, que hace de una circunstancia miserable un espacio de exploración que resulta ahora universalmente válido. Aquí hay una grieta, por la que ir más allá de las teorías que sólo producen comentarios de sus comentarios. He aquí la esperanza momentánea de una forma"69

O cinismo possibilita que o escritor tenha a consciência de que os interlocutores do Ocidente não o lerão nem o considerarão como produtor de discursos, o que demostra sua apatia. Ao sabe-lo e decidir seguir escrevendo, ele alega explorar a rachadura, o espaço intersticial que the permite produzir uma teoria, converter o invisível em continente. A palavra, a escrita, se transforma em ação, descrita por ele como "forma", e não apenas diálogo com outras teorias. Novamente com Lalo:

"El escritor invisible se ha apoderado del gesto/acto/palabra cínico, al enfrentarse con una tradición que no lo ve ni escucha, pero que habla en su nombre, lo clasifica, lo estereotipa, pretende no dejarle otros "lugares" que los de la rápida visita turística o el alarido. Como Diógenes, el que se enfrenta a ese Occidente, que es una formación del espíritu y de la geopolítica, desde una tradición invisible, se masturba en un ágora convertida en texto, ante las miradas atónitas o divertidas de los ciudadanos "cosmopolitas" que pretenden no ver el salto de la esperma. Como Diógenes, sólo tengo como patrimonio una herencia de huecos, el silencio que se crea a mi alrededor y mi-cuerpo-hechotransparente-por-la-mirada-ajena. [...] Así, con estas posesiones equiparables al morral, el manto y el báculo del filósofo, sin casa pero con un cuerpo, que es a la vez la contundencia de las piernas dispuestas al camino y la voluntad de la voz, que no calla aunque no la escuchen, hago el gesto/acto/palabra de este texto"70

O cinismo possibilita que o escritor de um país invisível enfrente esta condição de invisibilidade. A praça pública em que Diógenes se masturbava, o local do enfrentamento é, para o escritor, o texto. O ato de masturbar-se corresponde à escrita. 
Ser de um país invisível e ousar escrever estaria de acordo com o segundo fundamento do cinismo, a liberdade em relação às convenções sociais, neste caso, de ser engolido pela tradição ocidental. Escrever é também tornar-se transparente, mostrar tudo para os olhares alheios que analisam o produto de uma voz cínica. O próprio autor diz "lo invisible no es silente". A aniquilação ocidental não conseguiu eliminar a escrita dos que a realizam a partir do entre lugar invisível.

$O$ ato de escrever, de enfrentar o Ocidente e suas escritas, contrasta com aquele que apenas recorre a ela via leitura. Escrever significa alterar. A escrita de quem provém de um país invisível coincide novamente com a filosofia cínica na medida em que implica uma ação, uma alteração, ela necessariamente toma forma. O que ocorre, mais do que coincidir com o cinismo, é amparar-se nele e encontrar aí um resguardo, um antecedente histórico que enfrentou a tradição. 


\title{
CAPÍTULO III - O ENSAIO, O ESPAÇO NACIONAL, A DIVERSIDADE
}

\author{
“¿Por qué ahora la palabra Kalahari?” \\ Luis Palés Matos
}

Tuntun de pasa y grifería

No poema "Kalahari", de Luis Palés Matos, o eu lírico se depara, em meio às atividades cotidianas, com a lembrança da palavra "Kalahari", com a qual não se recorda ter nenhum contato. O surgimento inexplicável dessa palavra, que estava escondida em sua memória, traz à tona importantes questões sobre o pensamento rizoma. Se considerarmos a formação das sociedades caribenhas, levamos em consideração um enorme processo de extermínio de saberes. Os povos migrantes da Europa chegaram ao Caribe portando toda sua bagagem cultural. Os africanos, por outro lado, chegaram despojados de tudo, até mesmo de sua língua. A recomposição desta perda se dá por meio da articulação de rastros e resíduos, resultando em uma língua crioula e manifestações artísticas dela oriundas que se tornam válidas para todos. É neste contexto que aparece a palavra Kalahari. Por mais que haja um constante esforço do apagamento dos saberes para a consagração de um saber único como autorizado e válido, existe o rizoma, um pensamento que vai ao encontro de distintas raízes e que as incorpora na formação de uma cultura compósita. Este processo se contrapõe à implementação de um pensamento de sistema, que postula uma falsa universalidade, tentando deixar de lado rastros da diversidade. Entretanto, eles sempre aparecem: “¡Kalahari! ¡Kalahari” ¡Kalahari!”.

Nos dois capítulos anteriores, mostramos a construção do "¡Kalahari!" de Eduardo Lalo, ou seja, das imagens e representações que o ensaísta constrói para postular que, ainda que haja um esforço do Ocidente para apagar determinados territórios, a questão da política da invisibilidade sempre aparece. No primeiro capítulo, ela aparece através do desenvolvimento de uma perspectiva baseada em reminiscências portorriquenhas que navegam com o autor pelo continente europeu. Por outro lado, a construção de uma San Juan de leituras e escrituras transforma um objeto passível de apagamento em um sujeito produtor de discursos. 
Neste capítulo, trataremos de como a enunciação e a textualidade do ensaio reverberam o Kalahari de Lalo. Para isso, descreveremos a poética que 0 autor constrói e como o gênero textual escolhido - o ensaio - possibilita a criação dessa poética e dialoga com as imagens analisadas anteriormente. Por fim, versaremos sobre a ideia de nação desenvolvida no texto e em que medida ela corrobora a política de invisibilidade nele descrita. O conceito de Relação, formulado por Édouard Glissant, nos auxiliará a unir "nação" e "diversidade", tal como realizado por Lalo, em contraposição à homogeneização que o signo "nação" tende a exercer.

\subsection{A estruturação do ensaio}

"El que piensa es el que escribe", afirma Liliana Weinberg no livro Situación del ensayo, ao definir uma das características desse gênero textual. Estamos diante de um gênero textual que possui duas vertentes simultâneas: enquanto o ensaísta elabora seu juízo, sua opinião e interpretação a respeito de determinado tema, ele nos mostra como o faz, o processo de julgamento em si, por meio da escritura. A performance da formação deste juízo se dá concomitantemente à exposição do juízo mesmo, resultado desta performance. Se estamos, por exemplo, lendo um texto de crítica literária, o autor não tem interesse em mostrar ao leitor a maneira como suas conclusões foram obtidas, apenas as conclusões em si. Por isso, um texto crítico não remete necessariamente ao tempo presente, já que o processo de desenvolvimento de seus argumentos não se apresenta ao mesmo que eles. O ensaio, por outro lado, se finca no presente da escrita, pois o processo do pensar e o pensamento que dele resulta figuram igualmente no texto. A enunciação do julgar e do que foi julgado coexistem. O pensar uma tese no ensaio se escreve junto à apresentação dessa tese. O tempo presente implica em um "yo-aquí-ahora" que relaciona sujeito, espaço e tempo.

Ao longo de todo Los Países Invisibles, Eduardo Lalo constrói representações de si mesmo. Nos trechos "De aquí que el lector tenga, por lo que pueda ver, un fragmento de ese ser de papel y tinta que es Eduardo Lalo [...]" ${ }^{\text {" e }}$ "Imagino, o más bien alucino, el portento de poder escribir un día como punto final de algún texto: "Aquí deja de escribir para siempre Eduardo Lalo"'”72, podemos observar a concepção de um 
sujeito duplo. O uso que Lalo faz da primeira pessoa contrasta, nos excertos mobilizados, com sua autorreferência em terceira pessoa, como se estivesse referindo-se a alguém que não ele mesmo. O ensaio apresenta um desdobramento do sujeito que escreve. O uso da primeira pessoa neste gênero representa um encontro entre a voz do emissor real e sua representação no texto, de forma que o ensaísta se transforma em autor e ator ao mesmo tempo. Nestes momentos, o ator, Lalo como ensaísta que escreve e dialoga conosco, se desdobra em autor que cria personagens, no caso dele mesmo. Este yo consegue articular o enunciador com a sua representação artística no presente da escrita.

No que concerne à construção do espaço e do tempo, aquí - ahora, é possível tratar de diversos aspectos do livro. A primeira parte, o diário escrito na Europa, conta a viagem no tempo presente, o que difere dos diários em que o escritor relata a posteriori algo que viveu. Os verbos conjugam-se no presente do indicativo: "viajo", "descubro", "reflexiono", "imagino". Assim, é como se a escritura do diário se desse enquanto as coisas acontecem, como uma escrita fragmentária da realidade. Conforme o próprio autor alegou em uma entrevista, seu processo criativo se dá com uma mochila nas costas enquanto caminha com um caderno na mão. O diário escrito no tempo presente instaura uma escrita que se faz simultânea aos acontecimentos relatados. O leitor acompanha o que o Lalo ator vive e o que o Lalo autor escreve. Ator, autor e leitor estão em um mesmo tempo-espaço. No trecho "Escucho por la noche el pequeño transistor que he traído. Una emisora cualquiera donde suena mucha música en inglés: canciones que no se han escuchado en todo el mundo. Me admiro ante lo que me parece una forma básica de hastío [...]"73 podemos citar três atividades simultâneas: Lalo ator escuta música e se admira; Lalo autor escreve sobre o personagem de si mesmo que escuta música e se admira; o leitor realiza a leitura do ocorrido ao mesmo tempo em que ele sucede e é relatado.

As demais partes do texto também acompanham esta temporalidade. Ao longo do périplo de leituras de Lalo em "El experimento", estamos lendo com ele e acompanhando o processo de reflexão que gerará os argumentos apresentados em seguida. Tomemos por exemplo esta cena de escritura: "Ocupo esta mesa desde hace más de media hora, con sólo una taza de cartón sobre la bandeja que me entregaron 
al ordenar. Escribo y es de imaginar que me vean como esos locos que llenan página tras página sin poder detenerse" 74 . O uso do presente implica uma vez mais na escrita simultânea à ação. Esta escrita provém de leituras realizadas com seus leitores, como em "leo la última anotación de una vieja libreta: "San Juan es también donde el mundo no ha terminado"75. A descrição do ato de leitura, seguida da transcrição do que é lido, permite que ator e leitor leiam o excerto juntos. O processo do pensar está exposto e escrito pelo autor.

Por outro lado, a marcação do espaço, aqui, se dá pontualmente nas partes de diário, através do cabeçalho com o nome da cidade e a data do registro. Em última instância, arriscaríamos afirmar que a conjunção dos sujeitos (autor, ator e leitor) em tempo e espaço determinados promove uma unidade textual na qual o que se lê é "estamos aqui - eu, Lalo autor; eu, Lalo ator; você, leitor - e isso está acontecendo agora enquanto eu escrevo e vocês me leem". Nas demais partes do texto, a cidade de San Juan está marcada através das descrições do caminho e dos espaços por onde autor e ator circulam: ruas, cafés, shoppings, estradas, livrarias. A mesma conjunção explicada anteriormente se aplica: yo-aquí-ahora. Em todas as partes do livro, o que se apresenta poderia comparar-se a uma fotografia selfie enviada em tempo real, na qual aparecem o modelo da imagem, que é ao mesmo tempo o fotógrafo, mostrando a quem a vê o que ocorre no momento. O ensaio consiste nessas selfies que geram reflexões. Ver a selfie nos permite entender o processo formativo de tais reflexões. Nas palavras de Liliana Weinberg: "el texto remite así tanto a la situación enunciativa del ensayista como a la interpretación general que se está llevando a cabo para un destinatario que asiste a ella en su mismo despliegue"76.

O ensaio, por apresentar uma proposta de discussão e uma opinião sobre um assunto, insere-se no mundo, na cultura na qual se inscreve. Não obstante, o mundo também se insere no ensaio: é a dialética entre a prosa do ensaio e a prosa do mundo, como descrito por Weinberg. O texto de Lalo media a narrativa, um diário de viagens e textos críticos, enquanto mobiliza-os em pró da discussão que o move: a política da invisibilidade. Essa mediação intra e extra textual - dos gêneros no texto e do texto no mundo - possibilita a configuração de sua forma. A forma da prosa do ensaio de

\footnotetext{
74 $75 \longrightarrow$ p. 139

${ }^{76}$ WEINBERG, Liliana. Situación del ensayo. D.F.: Universidad Nacional Autónoma de México, 2006, p.62.
} 
Lalo encontra sua liga ao colocar-se no presente - yo, aquí, ahora - para representar e reinterpretar a questão da invisibilidade. Essa é a forma engendrada pelo pensar de Lalo, a qual, por sua vez, permite que o leitor se insira em um campo intelectual e literário específico.

Contudo, existe uma outra área que este ensaio nos permite acessar. Recordemos, com Weinberg, que existem dois universos que compõem um texto ensaístico: más allá e más acá, definidos, respectivamente, por uma ideia de macro e de micro. O primeiro trata da articulação da literatura com uma forma de ver o mundo própria de uma cultura. Esta visão e esta cultura são acessíveis ao leitor através do próprio texto. O segundo, por sua vez, consiste na rede de discursos, práticas, leituras e polêmicas nas quais o texto está inscrito. São fatores inerentes à ordem específica do campo literário e também são acessíveis pelo texto. Logo, um ensaio permite que seu leitor entre em contato com o más allá e o más acá do texto ${ }^{77}$.A caixa preta do ensaio, que permite entendê-lo em sua chave de sentido, é acessível se detectamos esses dois elementos que o constituem. No caso de Los Países Invisibles, o más allá é a política da invisibilidade e o más acá, todas as referências e influências que Lalo mobiliza para acessar esta política, extensamente analisadas ao longo dos capítulos anteriores.

A articulação da definição de uma política de invisibilidade, formulada através de referências literárias, ocorre por meio da construção de um yo-aquí-ahora que opera no presente da escrita e da leitura, concomitantemente. Isto permite que o processo do pensamento se exponha junto com seu resultado, formando uma poética do pensar exclusiva de Los Países Invisibles. Nela também se insere, por exemplo, a utilização do mecanismo de leitura-escritura descrevemos. Cabe acrescentar que o processo de uma leitura que gera uma escritura é integralmente exposto para o leitor enquanto ele se dá. Sendo assim, nos inteiramos de como se dá a performance da leitura, do que é lido e do resultado desse processo. Este aspecto reitera o presente

\footnotetext{
77 Weinberg escreve: “[...] el más acá apunta al momento mismo de la enunciación de un acto de intelección, al decir y al pensar, y a las condiciones en que se da esa producción enunciativa, así como la inscripción del discurso ensayístico, en cuanto ejercicio de responsabilidad, en un conjunto de prácticas, representaciones y procesos de simbolización que sólo las herramientas desarrolladas en los últimos años por diversas vías de indagación [...] permiten entender a cabalidad. [...] Por su parte, el más allá del texto nos envía a su inscripción en un horizonte de sentido [...]. El más allá del texto representa su vínculo con la vida, el enlace con ese mundo de sentido que es fundamento del ensayo pero que no puede comprenderse a su vez como tal hasta tanto no se dé como instaurado por el propio ensayo, en un doble movimiento de implicación que nos lo muestra como causa y consecuencia a la vez de ese momento de intelección fundacional propio de todo ensayo" (WEINBERG, 2006: 59)
} 
do ensaio, ao lado da construção do sujeito, do tempo, do espaço e dos referenciais estabelecidos.

Outro aspecto que chama a atenção na poética de Lalo é o desenvolvimento de uma escrita ensaística que mobiliza as sensibilidades e os afetos. Apesar de possuir muitas características que o aproximam de uma tradição do gênero, conforme elencadas acima, há uma singularidade expressiva em relação à essa mesma tradição. Como sabemos, o lugar de enunciação do autor difere justamente por ser um escritor que não está dentro do sensível. Em um intento de reorganização desse sensível por meio de sua obra, Lalo utiliza esse lugar de outsider na construção de constantes referências à ausência. As coisas materiais que faltam em sua existência na ilha, à ausência de sua ilha dentro da construção do sensível ocidental, à inexistência de uma tradição literária que inclua sujeitos invisíveis. Todas essas carências estão presentes no texto através da raiva, do uso de um tom que escancare tudo isso para seu interlocutor. A carência, a falta, a ausência e a inexistência the possibilitam construir um lugar de enunciação desde fora do sensível que o diferencia dos demais ensaístas latino-americanos dos quais trataremos a seguir.

Após descrevermos os aspectos discursivos do ensaio analisado, resta tratarmos sobre a seleção deste gênero frente à tradição que ele possui na América Latina enquanto instrumento para afirmação de identidades (continentais e nacionais). Eduardo Lalo não se insere na linha de um ensaio filosófico, mas de um pensamento latino-americano que versa sobre a identidade do continente. A seguir, realizaremos um recorrido pela formação desta linha ensaística, pelos aspectos que estavam por trás dela e por alguns textos importantes desta corrente.

\subsection{Um gênero nacional para um Estado Livre Associado}

No século XIX, a América Latina enfrentou uma onda de independências e de processos emancipatórios que culmina na formação de Estados Nacionais. A Espanha perdeu seu poder de potência metropolitana e a ascensão dos Estados Unidos como potência mundial no final do mesmo século transformou este país em uma ameaça. Assim, os intelectuais latino-americanos necessitavam encontrar um lugar para o continente neste cenário. Trataremos da América Latina como um espaço de desenvolvimento do ensaio de identidade e do intelectual como aquele que porta o dever e a tarefa de falar sobre o continente. 
Existem dois aspectos a serem considerados nesta mudança: o nacionalismo e uma espécie de visão continental latino americanista que deriva dele. Para isso, o pensamento latino-americano deveria gerar uma teoria que reafirmasse essas mudanças de paradigmas. De certa forma, buscava-se garantir que a ideia de nação e de continente propagada reiterasse os sujeitos letrados, provenientes de classes médias e altas, brancos e criollos, das principais cidades do continente e falantes das línguas metropolitanas (espanhol, francês e português).

Estamos, então, frente à Modernidade, um processo histórico e material. Qual o papel do intelectual frente a esse processo? Aqui cabe revisar a geração de 1900 e as vertentes históricas e estéticas deste latino americanismo, a saber, o liberalismo político e econômico e o positivismo filosófico. As condições de implementação do liberalismo político começam a aparecer a partir da segunda metade do século XIX. Os novos estados que se formam deveriam ser liberais, ou seja, ter como objetivo o alcance da ordem, do progresso, da organização e da pacificação. Pela primeira vez, após guerras civis, essas nações começam a se organizar e separam, por exemplo, Estado e Igreja. Isto se dá, mais concretamente, por meio da adoção de medidas como o registro de morte e de nascimento feitos pelo Estado, assim como os demais registros civis. O mesmo órgão assume a responsabilidade pela educação e eclodem pelo continente leis de educação gratuita e obrigatória. Na área econômica, temos a adscrição do continente ao sistema capitalista, que estava em expansão na Europa, mais precisamente na Inglaterra.

Os limites desse liberalismo eram a desigualdade e o apego do poder às estruturas coloniais, principalmente em zonas andinas e no Caribe, pois as novas estruturas políticas implementadas funcionavam com sistemas econômicos que ainda remontavam ao período colonial. Entretanto, é importante ressaltar que este liberalismo político e econômico gera um corpus ideológico que permite a hegemonia das elites dirigentes. Os escritores e intelectuais conservam sua posição na cidade letrada e procuram um locus estético a partir do qual possam produzir.

No campo da filosofia, apresenta-se o positivismo. Fundado por Augusto Compte, possuiu três etapas que permitiam conhecer as leis do desenvolvimento da sociedade e encaminha-la ao progresso: teológica, metafísica e o método científico. A sociedade era vista como um organismo em desenvolvimento constante e permanente e a educação deveria ser científica, impregnada de um utilitarismo. $O$ 
resultado deste modo de conceber a sociedade pode ser exemplificado com acontecimentos como a fundação da primeira escola pré-universitária no México em 1867 por um discípulo de Compte, a realização de reformas educativas em diversos países, o prevalecimento de um enciclopedismo, entre outros. O positivismo se impregna no discurso dos intelectuais que estavam tentando entender a posição da realidade latino-americana frente às mudanças mencionadas. Podemos afirmar, portanto, que a vida intelectual do final do século XIX, deriva da ciência. No que diz respeito à população, emerge um eu coletivo que deriva, principalmente, da ideia de nação e identidade coletiva forjada pelos processos emancipatórios. Os intelectuais percebem que apenas o liberalismo não é suficiente para comandar essas massas e o cenário político começa a ser marcado pela presença de multidões modernas que reivindicam seus direitos. Neste cenário, surge a figura de Ariel como uma resposta do intelectual, recuperando a metáfora de William Shakespeare em $A$ Tempestade e denotando novos papéis à trinca de personagens shakespearianos.

O ensaio de José Enrique Rodó é o primeiro que mencionaremos aqui como representativo do gênero na América Latina. Antes de comentarmos o texto, cabe ressaltar que o cenário do Uruguai em 1900, ano de sua publicação, se assemelhava a muitos ao redor do continente. Podemos resumi-lo em: idealismo, americanismo e aristocratismo cultural, fatores também presentes no texto de Rodó. O arielismo se dá em um momento em que a heterogeneidade e suas contradições estão latentes, entre as quais se encontram o cosmopolitismo versus o nacionalismo, o coletivo versus o individual, o elitismo cultural (aristocracia do governo) versus a democracia social (recusa a esta postura oligárquica).

Qual o tipo de enunciador que se delineia neste texto? O intelectual que viaja e traz para a América Latina a importação de valores culturais estrangeiros, de países considerados mais desenvolvidos, que o escritor adota como base. A ensaística de 1900 configura-se como um espaço político que coloca uma nova inteligência em função dos desejos de velhos patrícios. O discurso da oligarquia dominante segue em produção. A prosa deste ensaio é escrita a modos de um discurso para ser lido e compreendido por um público, como em uma oratória ou uma prosa sacerdotal.

Em Ariel, há uma preocupação pelo futuro da sociedade. Paira no texto um medo à que uma barbárie domine a sociedade. Para evita-lo, é necessário voltar ao humanismo e adotar ideias positivistas. O sujeito enunciador, Próspero, é o próprio 
Rodó (autor versus ator, conforme expusemos anteriormente), e ele cria uma distância de seus discípulos ao longo do ensaio. Seus ouvintes são os responsáveis pelo progresso, ao passo que o mesmo Próspero será o professor que guiará suas almas. Através de exemplos literários, históricos e citações, constrói um discurso com função de ideologizar. Há a contraposição do corpo espiritual - a alma - com o corpo de trabalho - o utilitarismo. Próspero pede que seus discípulos privilegiem o primeiro frente ao segundo, e posiciona os Estados Unidos como a nação que propaga o utilitarismo pela América Latina, o qual deve ser erradicado.

Este ensaio ecoou nos que o seguiram pelo continente. Um exemplo é o já mencionado Insularismo. Ensayos de Interpretación Puertorriqueña (1934), de Antonio S. Pedreira, que possui o mesmo tom pedagógico e ideológico, depositando fé na juventude portorriquenha para que ela se afaste dos males propagados pelos Estados Unidos. No ensaio de Pedreira, também há um apelo para que se retorne aos valores do espírito, da alma, mas que, para o portorriquenho, à diferença do uruguaio, consistiriam na retomada daqueles trazidos pela Espanha. Ambos descartam e desprezam, a sua maneira, a figura de Calibán. Pedreira não o menciona diretamente, mas a imagem calibanesca é traduzida por menções aos taínos e aos escravos africanos.

Ao prosseguirmos com essa linhagem ensaística que relê e se apropria do texto sheakesperiano, Roberto Fernández Retamar, em 1971, publica Caliban e ressignifica toda discussão realizada por Rodó. O autor cubano apresenta uma nova resposta para a pergunta sobre quem são os latino-americanos frente ao imperialismo em vigor e, apesar de insistir na mesma metáfora que busca definir o continente, desenvolve-a de maneira distinta. No texto de Retamar, Ariel também é um monstro. $O$ cubano escreve um texto emancipatório que rompe com o paradigma colonial arielista recriado pelo uruguaio. Retamar escreve:

“Nuestro símbolo no es pues Ariel, como pensó Rodó, sino Calibán. Esto es algo que vemos con particular nitidez los mestizos que habitamos estas mismas islas donde vivió Calibán: Próspero invadió las islas, mató a nuestros ancestros, esclavizó a Calibán y le enseñó su idioma para entenderse con él: ¿Qué otra cosa puede hacer Calibán sino utilizar ese mismo idioma para maldecir, para desear que caiga sobre él la «roja plaga»? No conozco otra metáfora más acertada de nuestra situación cultural, de nuestra realidad. [...] En cuanto a Rodó, si es cierto que equivocó los símbolos, como se ha dicho, no es menos cierto que supo señalar con claridad al enemigo mayor que nuestra cultura 
tenía en su tiempo $-\mathrm{y}$ en el nuestro-, y ello es enormemente más importante"78

O latino-americano deveria, portanto, assumir a identidade de Calibán, etomando "Nuestra América Mestiza" declarada por José Martí. A figura calibanesca congrega toda a mistura latino-americana, em cuja todos os elementos devem ser valorizados, não apenas o europeu. Ao assumir essa identidade, o inimigo comum segue sendo os Estados Unidos, mas o paradigma de seu combatente muda.

Uma vez mais, essa discussão ecoa em distintos ensaios pelo continente, e a valorização da mestiçagem se propaga em outros ensaios como El País de Cuatro Pisos (1984), escrito pelo portorriquenho José Luis González. O objetivo deste ensaio era responder à pergunta: “¿Cómo crees que ha sido afectada la cultura puertorriqueña por la intervención colonialista norteamericana y cómo ves su desarrollo actual?". Primeiramente, González estabelece como referência ensaístas e intelectuais que consideram Porto Rico uma nação, como Eugenio María de Hostos e Pedro Albizu Campos, deixando de lado aqueles que negam esta vertente, como Antonio S. Pedreira. Então, versa sobre a formação da cultura nacional portorriquenha, sobre a qual afirma que:

"Si la sociedad puertorriqueña siempre ha sido dividida en clases, y si, como afirmamos al principio, en toda sociedad dividida en clases coexisten dos culturas, la de los opresores y la de los oprimidos, y si lo que se conoce como "cultura nacional" es generalmente la cultura de los opresores, entonces es forzoso reconocer lo que en Puerto Rico siempre hemos entendido por "cultura nacional" es la cultura producida por la clase de los hacendados y los profesionales [...]. Esa clase oprimida por la metrópoli era a su vez opresora de la otra clase social puertorriqueña, la clase formada por los esclavos (hasta 1873), los peones y los artesanos [...]. (Esa cultura, por cierto, sólo ha sido estudiada por la clase dominante como folklore, ese invento de la burguesía europea que tan bien ha servido para escamotear la verdadera significación de la cultura popular). Y de ahora en adelante [...] hablemos de "cultura de élite" y "cultura popular"”79

Podemos traçar um paralelo entre os produtores do que González chama "cultura de elite", que correspondem à figura de Ariel, e os que produzem a "cultura popular", assumindo a figura de Calibán. Retamar pauta sua discussão na

\footnotetext{
${ }^{78}$ RETAMAR, Roberto Fernández. Caliban. Disponivel em < http://bibliotecavirtual.clacso.org.ar/ar/libros/caliban/caliban1.pdf >. Acesso em 25/01/2020. PP. 33-34.

${ }^{79}$ GONZÁLEZ, José Luis. El Pais de Cuatro Pisos y otros ensayos. Río Piedras: Ediciones Huracán, 1989, pp. 1819.
} 
mestiçagem, enquanto González o faz por meio das classes sociais. Entretanto, ambos se referem à uma categoria que sofre para além das mazelas do colonialismo.

Após apontar essas diferenças entre ambas as culturas, González expõe sua tese sobre a formação da cultura popular como quatro pisos, sendo que o seguinte andar sempre se constrói sobre o anterior. Em sua argumentação histórico-social, o primeiro piso trata dos escravos africanos levados à ilha. O segundo piso é da onda migratória que levou à ilha refugiados das colônias hispano-americanas que lutavam pela sua independência e a Real Cédula de Gracias que, em 1815, amparou estrangeiros ingleses, holandeses, franceses etc. $O$ terceiro piso se estabeleceu em 1898 com a invasão norteamericana e, o quarto, em 1952, com o estabelecimento do Estado Livre Associado.

Esta discussão ensaística, na qual pontuamos dois momentos emblemáticos a publicação de Ariel e de Calibán - e seus ecos, permite afirmar que parte do ensaio enquanto gênero no continente latino-americano sempre esteve relacionado ao debate que versa sobre o nacionalismo e a identidade. Esses textos buscam, a sua maneira, responder perguntas sobre o que é ser latino-americano - ou de alguma nacionalidade específica, como a portorriquenha nos exemplos mencionados - frente às mudanças históricas promovidas pela modernidade. A revisão historiográfica realizada possibilita afirmar que a eleição do gênero ensaio por Eduardo Lalo possui este debate como seu más acá, é neste microuniverso que o texto está inserido. Porém, se o ensaio trata de questões referentes ao nacional, a pergunta a ser respondida é: que nação delineia Lalo em seu ensaio?

\subsection{Que nação é essa?}

A resposta para esta pergunta é: nenhuma. O ensaio de Lalo, apesar de construir um espaço nacional, não está falando de nenhuma nação. $O$ autor não advoga por nenhuma identidade. O próprio título denota: Los Países Invisibles. Apesar de ser portorriquenho, ter a ilha como contraponto de sua escritura na primeira parte e plano de fundo da segunda e da terceira, ela se torna uma metonímia da política de invisibilidade que Lalo cria e da qual participam muitos outros territórios, inclusive se eles fazem parte de países visíveis, como Valença, na Espanha, do qual Porto Rico, nos Estados Unidos, é paralelo. 
O ensaísta coloca em evidência os sujeitos performativos destes espaços geográficos invisíveis para que eles possam suplementar as pedagogias ocidentais que os apagam, que os subtraem dos começos, impedindo-os de existir enquanto nação. Para explicar esta afirmação, sensibilizaremos o texto "DissemiNação", escrito por Homi K. Bhabha em O local da cultura. O título dialoga com o conceito de disseminação de Jacques Derrida, que trata de um oscilar constante, uma contínua difusão de significados que não podem ser contidos nas categorias estruturais do texto ou em uma abordagem convencional dele. Os termos que se disseminam no texto de Bhabha são "povo" e "nação".

Para Bhabha, o tempo da nação é disjuntivo, duplo e cindido, dividido entre a pedagogia nacionalista e os retalhos da significação cultural. Esse tempo duplo permite ver que o conceito de "povo" se refere a (1) eventos históricos que permitem a existência de uma pedagogia nacionalista e (2) sujeitos de um processo presente, vivo, contemporâneo, de cujas experiências devem ser repetidamente transformadas em signos de uma cultura nacional. O autor chama essas temporalidades de (1) pedagógica e (2) performática, e a nação se escreve nesta ambivalência.

Em relação ao espaço do povo, ele representa (1) o poder de totalizar uma comunidade enquanto homogênea e (2) conter identidades diferentes dentro de uma população. Por um lado, (1) o povo é um objeto pedagógico cuja autoridade está na tradição e, por outro, (2) se constrói na performance da narrativa, inserindo o entrelugar, o signo diferenciador. Essa disseminação de significados de "povo", (1) e (2), permite a escrita dupla da nação. Essa escrita é uma disputa entre narração e contranarração, sendo que a primeira contém as comunidades imaginadas e a segunda, a rasura de suas fronteiras totalizadoras.

Enquanto o significado pedagógico triunfa e os limites são mantidos, a agressividade direcionada ao Outro é projetada para o exterior. Se todos dentro de uma nação são homogeneizados pela vontade de pertencerem a ela, o ódio ao diferente se canaliza aos que não pertencem a esta nação. Entretanto, ao considerar o povo como cindido, a nação deixa de ser o signo que homogeneíza a sociedade, pois o conflito pedagógico versus performativo coloca em evidência a diferença interior. O Outro deixa de pertencer ao exterior para ocupar o espaço dentro da própria nação. As temporalidades disjuntivas da cultura nacional mostram que o presente da história de um povo, o sujeito performático, destrói os princípios constantes da cultura 
nacional que retomam e reproduzem o passado nacional pedagógico e verdadeiro. $\mathrm{O}$ desentendimento trazido através do performático resistirá à totalização do pedagógico, perturbando e produzindo novos espaços de significação na escrita da nação.

O ensaio de Lalo não constrói uma nação em que um tempo-espaço pedagógico se opõe ao que não pertence aos seus limites territoriais. O conflito que se estabelece decorre de um sujeito performativo que coloca a constituição interna da nação em conflito consigo mesma. Pensando no exemplo portorriquenho desenvolvido por Lalo, não é possível conceber uma cultura nacional pacífica porque ela não inclui os portorriquenhos como sujeitos estadunidenses. $O$ que o pedagógico tenta fazer é apagar essas diferenças através da instauração de uma vontade de nacionalidade homogênea. Isto não é bem sucedido, pois ao longo de todo o ensaio o autor nos mostra essa tentativa de apagamento, fazendo com que este mecanismo se torne alvo de estranhamento. O mesmo ocorre, também, na menção à Valença em relação ao resto da Espanha. É no presente da performance que se constrói a contranarrativa da nação. Recordemos a relevância do tempo-espaço presente na constituição do ensaio como gênero que se soma, agora, à importância deste mesmo tempo-espaço na reivindicação de uma inserção em uma pedagogia da qual se foi apagado.

Por outro lado, ao ocupar esse entre lugar, os territórios invisíveis deixam de ser os que recebem o estranhamento enquanto Outro para se tornarem os que geram o estranhamento em uma revisão da pedagogia ocidental. Lalo escreve:

“¿Qué es la identidad?: las palabras que uso, las que pongo por escrito. ¿Qué es una identidad cuando los orígenes son irrecuperables o se han inventado? El Otro no me ve por pertenecer a una tradición invisible, ¿pero quién es el Otro sino la ficción de su invención, de sus leyes, de su grandilocuencia? He aquí, que lo que se nos ha dado por visible, es tan inmaterial como cualquier otra formulación de identidad"80

A identidade é, portanto, mais um resultado de uma temporalidade pedagógica e totalizadora, que escreve as narrativas nacionais. Esta temporalidade é gerada pelo Ocidente, que assume o papel de nação: "Equiparar Ocidente com Europa es uma forma de nacionalismo [...]"81. Porém, o ensaio apresenta uma contranarrativa através

\footnotetext{
${ }^{80}$ LALO, Eduardo. Los países invisibles. Madrid: Fórcola Ediciones, 2016, p. 144.

81 Ibidem, p. 146.
} 
dos sujeitos performáticos oriundos de territórios invisíveis que fazem com o que o próprio discurso pedagógico se enfrente a si mesmo e à sua imaterialidade. A operação realizada pelo portorriquenho em seu ensaio pode ser resumida pelo seguinte trecho de Homi Bhabha:

"O espaço pós colonial é agora "suplementar" ao centro metropolitano; ele se encontra em uma relação subalterna, adjunta, que não engrandece a presença do Ocidente, mas redesenha seus limites na fronteira ameaçadora, agonística, da diferença cultural que de fato nunca soma, permanecendo sempre menos que uma nação e dupla"82

Além de gerar o estranhamento nos territórios aos que pertencem numa menor escala, os invisíveis também o fazem em maior grau em relação à toda tradição ocidental. Desta maneira, a seleção do gênero ensaio se dá devido a sua inserção no debate intelectual latino-americano sobre identidade e nacionalidade - seu más acámas o faz ultrapassando a discussão de um caso específico e desenvolvendo uma política da invisibilidade que abarca distintos casos. Em resumo, a emergência de uma narrativa nacional híbrida, com o tempo e o espaço disjuntivos, coloca o passado pedagógico num anterior contencioso e abre o presente histórico para outras histórias. Este é o espaço nacional que o ensaio de Eduardo Lalo constrói.

\subsection{O espaço nacional em Relação}

Ao utilizar uma estratégia tão característica de um sujeito pedagógico como a escrita para expor os mecanismos com os quais este mesmo dispositivo pedagógico opera na sublimação das diferenças em pró de uma falsa homogeneidade - pois pulsa nela um presente performático que constantemente a suplementa -, Eduardo Lalo constrói uma nação que se levanta contra valores supostamente universais. Ao descrever e exemplificar amplamente sua política da invisibilidade e a maneira como ela opera, o escritor realiza a primeira contranarrativa da qual fala Homi Bhabha. A segunda se dá quando ele se apropria de textos marcadamente ocidentais - o diário de Cristóvão Colombo, por exemplo, para colocar esse sujeito performático em atividade.

O reconhecimento de uma subtração inicial e a capacidade de ocasionar um estranhamento dentro de um dispositivo que deveria ser homogêneo não implica na

\footnotetext{
82 BHABHA, Homi K. O local da cultura. Belo Horizonte: Editora UFMG, 2013, p. 270.
} 
construção de uma nação que se feche em si mesma. Esses territórios invisíveis, tal como concebidos por Lalo, não procuram ter sua "hegemonia" ou "homogeneidade" reconhecidas. O que se almeja é obter a possibilidade de coloca-los em Relação ao Ocidente, e não como passivos de um apagamento.

A ideia de Relação mencionada segue o pressuposto do martiniquense Édouard Glissant, para quem existem dois esforços que regem a posta em Relação: o Mesmo e o Diverso. O Mesmo seria o esforço que o Ocidente faz para sublimar as particularidades, enquanto o Diverso é o esforço do espírito humano para manter uma relação universal em cuja base seja a articulação das diferenças ao invés da imposição de um padrão. O Diverso introduz a Relação, a reivindicação estrutural de uma igualdade sem reservas, enquanto a ambição do Ocidente é impor um conjunto de valores particulares para o mundo como se fossem valores universais, anulando as particularidades nacionais de cada território.

Posteriormente, o autor reflete sobre as literaturas nacionais. Para ele, a literatura nacional é a necessidade de não desaparecer no cenário mundial. A obra teria duas funções: a de dessacralizar, de desmontar a maquinaria que sustenta determinado sistema, e a de sacralizar, de reunir determinada comunidade em torno de seus mitos, crenças, imaginário e ideologia, perpetuando-os. Em outras palavras: "[...] la función de sacralización sería el hecho de una conciencia colectiva ingenua aún, y que la función de desacralización es el hecho del pensamiento politizado"83. Dentro do que estabelecemos como espaço nacional no livro de Eduardo Lalo, ou seja, os territórios que sofrem com uma política de invisibilidade, podemos afirmar que todo o esforço do autor é no sentido de dessacralizar a pedagogia ocidental e sacralizar a voz dos que foram invisibilizados. Vimos que isto se dá, por exemplo, na construção de um insularismo cosmopolita, na apropriação de textos canônicos do ocidente, como os diários de Colombo e na apropriação da cidade letrada. Desde outra perspectiva, isto também se dá pela seleção de um gênero textual que possui um histórico de debates sobre a questão identitária. Os modos de operação do Mesmo são intensamente descritos por Lalo ao longo de seu texto. Aqui, demonstramos como o autor portorriquenho se constrói enquanto sujeito da enunciação para tratar desta maquinaria. Isto se dá por meio das cenas de leitura posteriormente apropriadas como

\footnotetext{
${ }^{83}$ Ibdem, p. 228.
} 
impulsionadoras de uma escritura ou da seleção do gênero ensaio que Eduardo Lalo - autor - realiza e nas implicações que isto possui ao inserir o livro em um debate do campo intectual sobre nacionalismo e identidade.

Se considerarmos que, na história do mundo, as culturas em contato se transformam, Eduardo Lalo defende que os territórios invisíveis sejam passivos de transformar quando em Relação, não apenas de serem transformados pelo contato. O processo deve ser de mão dupla, caso contrário se trataria de um apagamento e não uma Relação. A prática de uma poética da totalidade-mundo consiste na união do lugar de onde uma poética ou literatura é emitida à totalidade-mundo e vice-versa. A literatura provém de um lugar e servirá a este lugar na medida em que o relacionar com a totalidade-mundo. Se pensarmos no conceito de pensamento rizoma, que vai ao encontro de outras raízes, temos a função da literatura: entrar em Relação, existir enquanto cultura compósita.

O caos-mundo é o encontro das culturas dos povos na totalidade-mundo contemporânea. Em Tratado del Todo-Mundo, Glissant escreve:

"Llamo Caos-mundo al actual choque de tantas culturas que se prenden, se rechazan, desaparecen, persisten sin embargo, se adormecen 0 se transforman, despacio o a velocidad fulminante: esos destellos, esos estallidos cuyo fundamento aún no hemos empezado a comprender, ni tampoco su organización, y cuyo arrebatado avance no podemos prever. El Todo-Mundo, que es totalizador, no es (para nosotros) total.

Y llamo Poética de la Relación a esa posibilidad de lo imaginario que nos mueve a concebir la globalidad inasible de un Caos-mundo como ése, al tiempo que nos permite hacer que despunte algún detalle $\mathrm{y}$, muy particularmente, nos permite cantar el lugar que nos corresponde, insondable e irreversible" 84

Eduardo Lalo faz uso dessa poética da Totalidade-mundo na medida em que utiliza sua escrita para defender que territórios invisíveis, culturas compósitas, possam entrar em Relação quando em contato com as culturas atávicas do Ocidente. Há uma intercessão pelo direito daqueles que habitam os países invisíveis a adentrar o Caosmundo através da posta em Relação dessas culturas com valores pedagógicos do Ocidente, promovendo, por fim, uma mudança de paradigmas.

\footnotetext{
${ }^{84}$ GLISSANT, Édouard. Tratado del Todo-Mundo. Barcelona: El Cobre Ediciones, 2006, pp. 25-26.
} 


\section{CONCLUSÃO}

Em seu livro Los Países Invisibles, Eduardo Lalo constrói um ensaio com todos os traços característicos desse gênero textual: sujeito, tempo e espaço localizados no presente, leitura e escrita que se retro alimentam simultaneamente, inserção do texto dentro do campo literário e do mundo exterior a ele porém que se podem conhecer exclusivamente através do texto, uso de uma situação disparadora que desencadeia uma reflexão a respeito de um tema e descrição do processo de pensar esta reflexão, não apenas do resultado em si. A subversão reside na construção de um texto tipicamente ensaístico para apresentar uma teoria que caminha no sentido oposto ao que certa vertente tradicionalmente latino-americana do ensaio se desenvolveu.

Como explicamos, existiu uma linha ensaística na América Latina que se concentrou na questão identitária, buscando posicionar e definir os que aqui viviam frente às ameaças de dominação estadunidense e o ex colonialismo espanhol. Dela surgiram textos emblemáticos como Ariel e Calibán que, ao se apropriarem da metáfora de Shakespeare, desenvolveram representações para os sujeitos latinoamericanos.

O ensaio de Lalo também busca representar um grupo de sujeitos, mas a formação deste grupo não se baseia em uma unidade ou homogeneidade como uma nação ou um continente. O agrupamento que é objeto do autor é marcado pelo pertencimento a um território que padece da invisibilidade propagada pelo Ocidente, sofrendo com as ausências e carências que este não pertencimento ao sensível ocidental gera. Esta invisibilização consiste em aniquilar os discursos que estes sujeitos produzem e gerar outros sobre eles, falar por eles. O processo de Lalo consiste em trazer esta política de invisibilidade à superfície, mostrar como ela opera e, através disso, fazer com que estes invisíveis perturbem a homogeneidade e universalidade da nação à qual pertencem e até mesmo do Ocidente como um todo que, para o autor, se assemelha ao papel que uma nação cumpre na função de apagamento de certos grupos. $O$ autor permite que esses territórios entrem em Relação com a Totalidade-mundo, num processo de mútua influência e mudança e não apenas como objetos passíveis de serem apagados e eliminados em um encontro de culturas. 
Apesar de versar sobre países invisíveis como um todo, incluindo distintos territórios, o caso de Porto Rico se sobressalta no ensaio. A construção de uma perspectiva portorriquenha é o que lhe permite desenvolver sua teoria e alimentá-la estando, por exemplo, no continente europeu. Isso se dá com a apropriação do mar que rodeia a ilha enquanto um modo de que os dela oriundos possam flutuar ao longo de todo o mundo. O mar se torna um meio de expansão e não um fator geográfico que limita. Essa disseminação da perspectiva portorriquenha através do mar, ao que chamei insularismo cosmopolita, permite que sujeitos antes lidos pela tradição ocidental como "ninguém" se tornem "alguém". Na prática isso implicou, por exemplo, na tomada de textos que fizeram parte direta desse processo de invisibilização, como o diário de Cristóvão Colombo, e sua reescritura por um portorriquenho que viaja pela Europa.

Não apenas o elemento marítimo participou dessa posta em Relação, o urbano também ocupa um papel fundamental no processo. Através de um jogo duplo enquanto indivíduo pertencente à cidade letrada, Lalo altera a estrutura desta camada, inserindo os invisíveis dentro dela. No que concerne ao delineamento de sua própria San Juan, o autor o faz através de um périplo de leituras geradoras de escrituras e que, pouco a pouco, constroem a representação que o ensaísta possui de tal território. A imagem que ele constrói dessa cidade une suas experiências nela, o ideal que ele possui de cidade e a cidade real. $O$ que prevalece é a cidade real e a consequência disto é a construção de si mesmo como um cínico.

Através do texto, o autor consegue realizar distintas apropriações da tradição ocidental e configurar-se enquanto sujeito produtor de discursos. Com sua escrita, Lalo expõe o modo de funcionamento do mecanismo de invisibilização e questiona toda a lógica que rege o mundo moderno através de identidades que insistem em apagar as diversidades. $\mathrm{O}$ ensaio demonstra que o pertencimento a uma maneira de existir no mundo pré-determinada é tão imaterial quanto o próprio estabelecimento dessa lei de existência. 


\section{BIBLIOGRAFIA}

ANDERSON, Benedict. Comunidades Imaginadas. Reflexiones sobre el origen y la difusión del nacionalismo. México, D.F: Fondo de Cultura Económica, 1993.

AVILÉS, Francisco Javier. Estética del derrumbe: escritura y deambular urbano en la obra de Eduardo Lalo. In: Revista Iberoamericana. Volume LXXVIII, número 241, pp. 873-892.

BAGGIO, Kátia Gerab. A questão nacional em Porto Rico: o Partido Nacionalista (1922-1954). São Paulo: FAPESP: Annablume, 1998.

BALAKRISHNAN, Gopal (org). Um mapa da questão nacional. Rio de Janeiro: Contraponto, 2000.

BARTHES, Roland. O rumor da língua. São Paulo: Martins Fontes, 2004.

BENJAMIN, Walter. Desempaco mi biblioteca. Un discurso sobre el coleccionismo. In: Cuadernos de la Lectio, ํㅜㄱ, enero-julio 2018.

BHABHA, Homi K. O local da cultura. Belo Horizonte: Editora UFMG, 2013.

BLANCO, Tomás. El prejuicio racial en Puerto Rico. Río Piedras: Ediciones Huracán, 1985.

CALVINO, Italo. Las ciudades invisibles. Buenos Aires: Ed. Minotauro, 1984.

CAMPOS, Pedro Albizu. La conciencia nacional puertorriqueña. Organização de Manuel Maldonado-Denis. Buenos Aires: Siglo XXI Editores S.A., 1972.

COLOMBI, Beatriz. La gesta del letrado (sobre Ángel Rama y La ciudad letrada). In: Orbis Tertius, 2006 11(12). Disponível em < https://www.orbistertius.unlp.edu.ar/article/view/OTv11n12a03 >. Acesso em 30/01/2020.

COSER, Stelamaris (Org). Viagens, deslocamentos, espaços: conceitos críticos. Vitória: EDUFES, 2016.

DEFOE, Daniel. Robinson Crusoé. São Paulo: Penguin Classics Companhia das Letras, 2011.

FANON, Frantz. Pele negra, máscaras brancas. Salvador: EDUFBA, 2008. 
FERNÁNDEZ RETAMAR, Roberto. Calibán. Disponível em < http://bibliotecavirtual.clacso.org.ar/ar/libros/caliban/caliban1.pdf >. Acesso em $25 / 01 / 2020$.

FOCAULT, Michel. A ordem do discurso: aula inaugural no Collège de France, pronunciada em 2 de dezembro de 1970. São Paulo: Edições Loyola, 2014.

GLISSANT, Édouard. El discurso antillano. Caracas: Monte Ávila Editores Latinoamericana, 2002.

. Introdução a uma poética da diversidade. Juiz de Fora: Editora UFJF, 2005.

. Tratado del Todo-Mundo. Barcelona: El Cobre Ediciones, 2006.

GONZÁleZ, José Luis. El Pais de Cuatro Pisos y otros ensayos. Río Piedras: Ediciones Huracán, 1989.

HALL, Stuart. A identidade cultural na pós-modernidade. Rio de Janeiro: DP\&A Editora, 2006.

HERENCIA, Juan Carlos Quintero. La escucha del desalojo: paseos y errancias en Cada Vez te Despides Mejor de José Liboy y donde de Eduardo Lalo. In: Katatay, Ano IV, n6, setembro (2008), pp. 17-24. Disponível em < http://sedici.unlp.edu.ar/handle/10915/10841 >. Acesso em 30/01/2020.

. La hoja de mar (:) Efecto archipiélago I. Leiden:

Almenara, 2016.

LALO, Eduardo. A escrita riscada. São Paulo: Selo Editorial Malha Fina Cartonera, 2016.

. "Entrevista a Eduardo Lalo", in Cuadernos hispanoamericanos, no 799, Janeiro/2017, p. 94-107.

Intemperie. Buenos Aires: Corregidor, 2016.

. La inutilidad. Buenos Aires: Corregidor, 2013.

. Los Países Invisibles. Madrid: Fórcola Ediciones, 2016.

Simone. Madrid: Fórcola Ediciones, 2016. 
LEZAMA LIMA, José. La expresión americana. México, D.F.: Fondo de Cultura Económica, 1993.

MARQUÉS, René. Ensayos (1953 - 1966). Barcelona: Editorial Antillana, 1966.

MINTZ, Sidney W. Three ancient colonies: Caribbean themes and variations. Harvard: First Harvard University Press, 2010.

NIEVES, Luis López. Seva. La Habana: Fondo Editorial Casa de las Américas, 2007. OLMOS, Ana C. Escritas descentradas: o ensaio dos escritores na América Latina. Rio de Janeiro: Papéis Selvagens, 2019.

PEDREIRA, Antonio. Insularismo. Ensayos de interpretación puertorriqueña. San Juan: Editorial Plaza Mayor, 2001.

PERUS, Françoise. ¿Qué nos dice hoy La ciudad letrada de Ángel Rama?. In: Revista Iberoamericana, Vol. LXXI, Núm. 211, Abril-Junio 2005, pp.363-372.

PINHEIRO, Tiago G. A literatura sob rasura: autonomia, neutralização e democracia em J.M. Coetzee e Roberto Bolaño. Tese (Doutorado)- Faculdade de Filosofia, Letras e Ciências Humanas, Universidade de São Paulo. São Paulo, 2014. PIÑERA, Virgilio. "La isla en peso" (1943). In: ARRUFAT, A. (ed.). Poesía y crítica. México D.F.: Cien del Mundo, 1994: 23-76.

QUIÑONES, Arcadio Díaz. Sobre los principios: los intelectuales caribeños y la tradición. Bernal: Universidad Nacional de Quilmes, 2006.

RAMA, Ángel. A cidade das letras. São Paulo: Boitempo, 2015.

RANCIÈRE, Jacques. Políticas da escrita. São Paulo: Editora 34, 2017.

ROJO, Antonio Benítez. La isla que se repite. Hanover: Ediciones del Norte, 1989.

SANTIAGO, Silviano. O cosmopolitismo do pobre: crítica literária e crítica cultural. Belo Horizonte: Editora UFMG, 2004.

SARLO, Beatriz. La ciudad vista. Buenos Aires: Siglo Veintiuno Editores, 2009.

WEINBERG, Liliana. El ensayo, entre el paraíso y el infierno. México: Fondo de Cultura Económica, 2001. 
Pensar el ensayo. México: Siglo XXI, 2007.

. Situación del ensayo. México: Universidad Nacional Autónoma

de México, 2006.

WINTER, Juan Duchesne. Desde donde alguien para leer a Eduardo Lalo. In: Katatay, Ano IV, no6, setembro (2008), pp. 7-16. Disponível em < http://sedici.unlp.edu.ar/handle/10915/10840 >. Acesso em 30/01/2020. Neonacionalismo y fatiga de identidad en Puerto Rico. In: ARBOR Ciencia, Pensamiento y Cultura. Número 724, março-abril (2007), pp. 265-274. Disponível em < http://d-scholarship.pitt.edu/26297/ >. Acesso em $30 / 01 / 2020$.

ZAMBRANO, María. Isla de Puerto Rico. Madrid: Visto Roto Ediciones, 2017. 